\title{
Bacterial Metabolites of Human Gut Microbiota Correlating with Depression
}

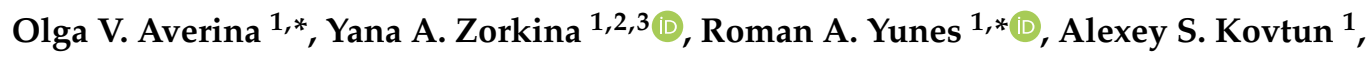 \\ Valeriya M. Ushakova ${ }^{2,4}$, Anna Y. Morozova ${ }^{2,3}$, George P. Kostyuk ${ }^{3}$, Valery N. Danilenko ${ }^{1,5}$ \\ and Vladimir P. Chekhonin 2,6 \\ 1 Vavilov Institute of General Genetics, Russion Academy of Sciences, 119991 Moscow, Russia; \\ zorkina.ya@serbsky.ru (Y.A.Z.); kovtunas@gmail.com (A.S.K.); Valerid@vigg.ru (V.N.D.) \\ 2 Department Basic and Applied Neurobiology, V.P. Serbsky Federal Medical Research Centre of Psychiatry \\ and Narcology, 119034 Moscow, Russia; Ushakovavm@yandex.ru (V.M.U.); hakurate77@gmail.com (A.Y.M.); \\ Chekhoninnew@yandex.ru (V.P.C.) \\ 3 Mental-Health Clinic No. 1 Named after N.A. Alexeev of Moscow Healthcare Department, \\ 117152 Moscow, Russia; Kgr@yandex.ru \\ 4 Department of Biology, Lomonosov Moscow State University, 119991 Moscow, Russia \\ 5 Faculty of Ecology, International Institute for Strategic Development of Sectoral Economics, \\ Peoples' Friendship University of Russia (RUDN University), 117198 Moscow, Russia \\ 6 Department of Medical Nanobiotechnology, Pirogov Russian National Research Medical University, \\ 117997 Moscow, Russia \\ * Correspondence: olgavr06@mail.ru (O.V.A.); romanyunes@gmail.com (R.A.Y.)
}

Received: 4 November 2020; Accepted: 2 December 2020; Published: 3 December 2020

check for updates

\begin{abstract}
Depression is a global threat to mental health that affects around 264 million people worldwide. Despite the considerable evolution in our understanding of the pathophysiology of depression, no reliable biomarkers that have contributed to objective diagnoses and clinical therapy currently exist. The discovery of the microbiota-gut-brain axis induced scientists to study the role of gut microbiota (GM) in the pathogenesis of depression. Over the last decade, many of studies were conducted in this field. The productions of metabolites and compounds with neuroactive and immunomodulatory properties among mechanisms such as the mediating effects of the GM on the brain, have been identified. This comprehensive review was focused on low molecular weight compounds implicated in depression as potential products of the GM. The other possible mechanisms of GM involvement in depression were presented, as well as changes in the composition of the microbiota of patients with depression. In conclusion, the therapeutic potential of functional foods and psychobiotics in relieving depression were considered. The described biomarkers associated with GM could potentially enhance the diagnostic criteria for depressive disorders in clinical practice and represent a potential future diagnostic tool based on metagenomic technologies for assessing the development of depressive disorders.
\end{abstract}

Keywords: gut microbiota; depression; gut-brain axis; biomarkers; neurotransmitters; aminoacids; functional foods; psychobiotics

\section{Introduction}

Depression is currently ranked fourth among the causes of disability worldwide [1]. Every fifth person in developed countries has been subject to a depressive disorder at some point, and the situation is even worse in third world countries. Depression is the most common type of psychiatric disorders today, making antidepressants some of the most commonly prescribed drugs [2,3]. According to the diagnostic and Statistical Manual of Mental disorders (DSM-5), major depressive disorder 
(MDD) is diagnosed sustaining the following symptoms for at least two weeks: depressed mood, excessive guilt, anhedonia, suicidal ideation, changes in appetite and sleep, psychomotor retardation, poor concentration, and fatigue. MDD is a complex and heterogeneous psychiatric disorder and no reliable biomarkers currently exist that have contributed to objective diagnoses and clinical therapy [4].

The known mechanisms of origin, development, and maintenance of a depressive state are multifactorial and are determined by polymodal changes in the metabolic, immune, endocrine, gastrointestinal, and central nervous systems (CNS) [5]. The gastrointestinal tract with its microbiota interacting with external environmental signals, stress, nutrients, internal systems, including the brain, may be involved in the development of depressive states too [6]. There is ample evidence for an association between the GM and the pathophysiology of depression [7]. Different stress (social or emotional, chemical, physical, a poor diet, etc.) have the potential to alter the taxonomic composition of bacterial communities in the gut, and, as a result, leads to changes in various metabolic pathways [8]. This leads to a systematic inflammatory process, which covers the other systems and organs of humans. Over the last decade, many literature reviews have described the relationship between the gut microbiome and depression, each from a slightly different perspective [9-12]. At the current level of research, the most important point is to identify various metabolite biomarkers that correlate with depressive states. Metabolic syndrome is well-documented in MDD patients and 1.5 times higher than in the non-depressed population [13]. Isolating those that can be determined directly or indirectly by the microbiome is of great importance, both for creating diagnostic systems for identifying depression as a disease, and for choosing strategies aimed at restoring the normal functioning of the microbiota and, through it, restoring human mental health.

This review examines various low-molecular compounds as potential biomarkers of depression in correlation with the metabolism of the GM, as well as ways to correct the microbiota.

\section{Role of the Gut Microbiome in the Gut-Brain Axis}

The gut microbiota is conceptualized as a virtual organ playing a key role in maintaining homeostasis and health in humans. The GM consists predominantly of bacteria which outnumber archaea, fungi, and viruses inhabiting the intestines by a ratio of 10:1 [14]. The collective genetic makeup of the GM contains 150 times as many genes as the human genome, thereby expanding the natural capacity of humans [15]. Numerous current studies of the GM revealed its active involvement in the bidirectional communication between the gut and the brain. The discovery of the microbiota-gut-brain axis (MGBA) induced scientists to study the role of the GM to neurological health [16-18]. Clinical and experimental findings are evident of the interactions occurring locally between the GM and the intestinal cells or the enteric nervous system (ENS), and also between this microbial community and the brain via neuroendocrine and metabolic pathways. The human GM is capable of producing hundreds of metabolites that directly affect most systems and organs, including the intestinal epithelium and the enteric nervous system, and also the brain [19].

The role of the intestinal symbionts in the development and function of the brain was studied in different animal models [20]. The obtained data demonstrate the enormous effect the commensals have on a wide range of behavioral aspects, including social behavior, mood, and anxiety. MGBA covers a wide range of immune and endocrine functions [21,22] and is a key player in the initial stage of central nervous system (CNS) development in humans [23]. Disturbances in the harmonious interactions between the microbiota and its host during critical stages of child's development can cause profound damage to gut-brain signaling pathways and put an individual at risk for psychiatric disorders later in life, including depression [16,24]. For instance, among the factors contributing to brain diseases is early life exposure to harmful food derivatives and small molecules derived from microbial metabolism, which first permeate into the bloodstream and then to the brain [25]. Thus, the identification of damaging early life events can help establish the causes of depression while diagnosing a patient. These include the exposure to antibiotics, unbalanced nutrition, stress, and other factors [26]. 
So far, a few major mechanisms mediating the effects of the GM on the brain have been identified. Among these are the activation of the vagus nerve [27-29] and the immune system [30,31], production of metabolites, and compounds with neuroactive properties [32,33]. Bacterial products participate in stimulation of central receptors, peripheral stimulation of neural, endocrine, and immune mediators, and epigenetic regulation of histone acetylation and DNA methylation, which are implicated in depression. (Figure 1).

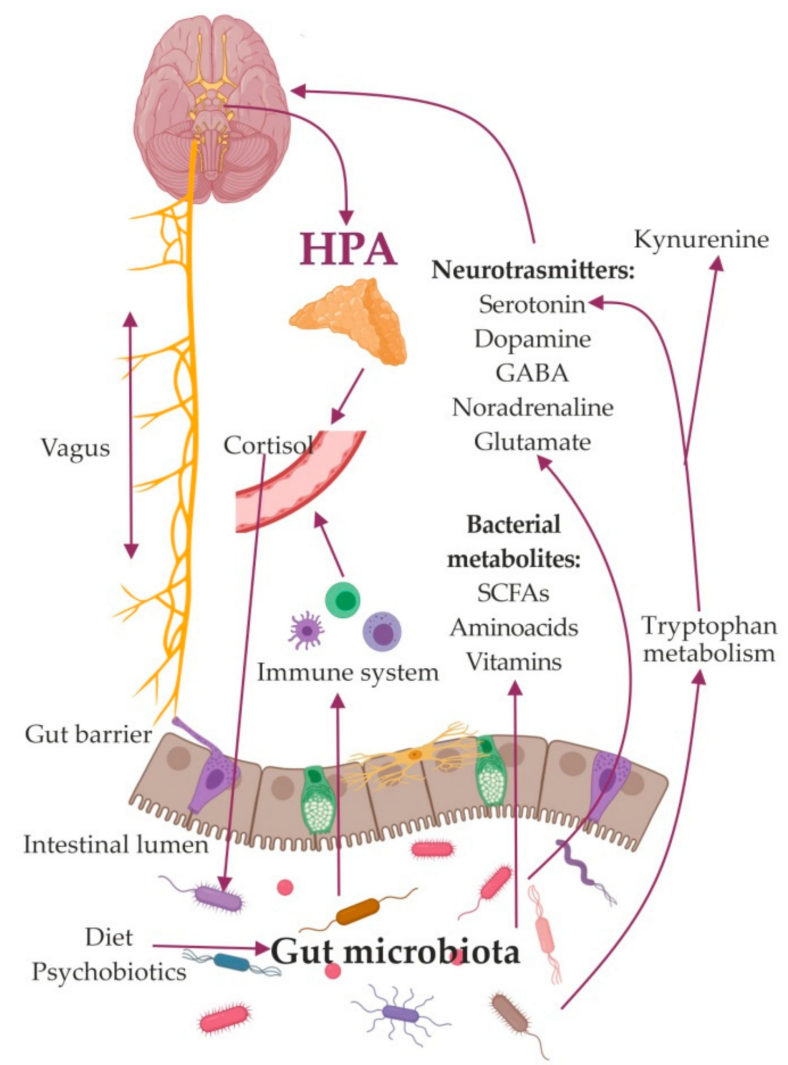

Figure 1. Schematic image of the role of the gut microbiome in the gut-brain axis.

The mechanisms found to be linked to depression also include a dysfunctional hypothalamicpituitary-adrenal (HPA) axis [34]; immune-inflammatory, oxidative pathways [35]; altered vagus nerve tone [36]; region-specific changes in brain-derived neurotrophic factor concentrations [37]; and an imbalance between neural excitation and inhibitory signaling [38].

Gut microbes may trigger neurotransmitter release via Toll-Like Receptor (TLR) signaling on epithelial, immune, and neuronal cells $[39,40]$. Bacteria can synthesize neuromodulators, stimulated specific epithelial cells of the intestines, to secrete molecules responsible for signal transmission through the enteric nervous system [31,32]. Using their own signaling pathways, they regulate the release of neurotransmitters from enterochromaffin cells [41-44]. Bacteria are called vectors because they can deliver neuroactive compounds to the receptors of epithelial cells. These bacteria-derived neuroactive compounds can play a significant role in modulating the signals of the GM caused by changes in concentration of ions $\left(\mathrm{K}^{+}, \mathrm{N}^{+}, \mathrm{Ca}^{2+}, \mathrm{Cl}^{-}\right.$, etc.), as well as exogenous agonists and antagonists coming from food. Thus, bacterial neuroactive substances can control depolarization in the synaptic area of neurons containing neurotransmitters. Bacteria can produce the neurotransmitters GABA, serotonin, dopamine, and acetylcholine [44,45], which can affect the emotional state by binding to specific receptors on nerve and immune cells in the central and peripheral nervous systems [8].

Elucidating these mechanisms is crucial for understanding the etiology of depression and developing new strategies aimed at harnessing the beneficial psychotropic effects of these molecules. 
It is also important to note that not all bacterial metabolites are beneficial. Some metabolites are rather harmful and conducive to depression.

\section{The Gut Microbiome of Patients with Depression}

A comprehensive literature analysis of human studies on the gut microbiome and depression showed significant differences between the GM of patients with depression and healthy controls [46,47]. Overall, the distinctive characteristic of the GM in patients with depression is a decline in richness and alpha- and beta-diversity $[48,49]$. In depressed patients, decreased microbial diversity was found in most studies. At the phylum level, there were inconsistencies in the abundance of Firmicutes, Bacteroidetes, and Proteobacteria. However, high abundance in Actinobacteria and Fusobacteria phyla were observed in people with depression [46]. Naseribafrouei et al. detected low abundance of the order Bacteroidales and a high abundance of the Lachnospiraceae, and Prevotellaceae families and the Prevotella species $[48,50]$. Higher levels of Bacteroidetes, Proteobacteria, and Acinobacteria, and lower levels of Firmicutes were also reported [48]. In the study of Liu et al. and Aizawa et al. the GM of patients with depression contained lower levels of Lactobacillus, Bifidobacterium, Firmicutes, Faecalibacterium, and Ruminococcus and higher levels of Prevotella, Bacteroides, and Proteobacteria [51,52]. Flavonifractor was reported to be increased in MDD patients [48] and Coprococcus and Dialister were consistently depleted [53]. Szczesniak et al. found that Faecalibacterium, Alistipes, and Ruminococcus correlated with depression [54]. Altogether, the recurrent pattern seen in depression is an overabundance of potentially harmful and inflammatory bacteria such as Actinobacteria and Enterobacteriaceae combined with a decrease in beneficial bacteria such as Faecalibacterium and Firmicutes in general $[48,50,55,56]$. Although all these studies focused on finding the distinctive features of the GM in depression, the constantly arising contradictions between them led to lack of consensus. It was argued that the contradictions are due to inconsistencies in the methodology between the studies such as the diagnostic criteria, grouping criteria, detection methods of fecal microbiota, etc. Hence, some of the suggested solutions to this problem include shifting from 16SrRNA sequencing to whole metagenome sequencing, which allows focusing on the functional capacity of the GM, a more significant indicator of its potential [57]. In addition, consistent demographic and clinical characteristics of recruited subjects are needed. The gut is a complicated ecosystem, which can be influenced by various factors such as, genetics [58], diet [59], age [60], and regional variations [61].

Today, scientists acknowledge that the GM is an organ fine-tuned to the pathological processes in the organism as exemplified by depression. The GM produces a wide array of metabolites, some of which correlate with symptoms of depression [62,63]. Some of these metabolites exhibit neuroactive properties and are involved in immunomodulation. Table 1 summarizes the bacterial enzymes involved in the production of many metabolites relevant to depression and Table 2 provides a summary of studies of altered metabolites in patients with depression. Studying the influence of the GM on the biomarkers of depression will greatly improve our understanding of its pathogenesis and our chances of diagnosing it accurately in the early stages before it escalates into a full-blown condition. In the following sections, we contemplate the bacterial metabolites that are potentially involved in depression. 
Table 1. Gut bacteria and their enzymes that are involved in the production of metabolites relevant to depression.

\begin{tabular}{|c|c|c|c|}
\hline Metabolite & $\begin{array}{l}\text { Bacterial Enzymes Involved in the } \\
\text { Production of the Metabolite }\end{array}$ & $\begin{array}{l}\text { Microbial Genera and Species Involved in the } \\
\text { Production of the Metabolite }\end{array}$ & Reference \\
\hline Serotonin & Aromatic amino acid decarboxylase & $\begin{array}{c}\text { Pseudomonas putida, Bacillus subtilis, Staphylococcus aureus, } \\
\text { Escherichia coli, Morganella morganii, Klebsiella pneumonia, } \\
\text { Lactobacillus helveticus, Lactobacillus plantarum, } \\
\text { Enterococcus faecalis, Lactococcus lactis subsp. cremoris, } \\
\text { L. lactis subsp. lactis }\end{array}$ & $\begin{array}{l}\text { Shishov et al., } 2009 \text { [64] } \\
\text { Özoğul et al., } 2004 \text { [65] } \\
\text { Özoğul et al., } 2012 \text { [66] } \\
\text { O'Mahony et al., } 2015 \text { [67] } \\
\text { Dinan et al., } 2015 \text { [68] }\end{array}$ \\
\hline Dopamine & DOPA decarboxylase & $\begin{array}{l}\text { B. subtilis, B. mycoides, B. cereus, S. aureus, P. vulgaris, } \\
\text { S. marcescens, E. coli, M. morganii, K. pneumonia, Hafnia alvei, } \\
\text { L. helveticus NK-1, L. delbrueckii subsp. bulgaricus }\end{array}$ & $\begin{array}{l}\text { Tsavkelova et al., } 2000 \text { [69] } \\
\text { Özoğul et al., } 2004 \text { [65] } \\
\text { Shishov et al., } 2009 \text { [64] }\end{array}$ \\
\hline Noradrenaline & Dopamine $\beta$-hydroxylase & $\begin{array}{c}\text { Bacillus mycoides, } \\
\text { B. subtilis, Proteus vulgaris, Serratia marcescens, E. coli }\end{array}$ & $\begin{array}{l}\text { Tsavkelova et al., } 2000[69] \\
\text { Shishov et al., } 2009[64]\end{array}$ \\
\hline GABA & Glutamate decarboxylase & $\begin{array}{c}\text { Bifidobacterium spp., } \\
\text { Lactobacillus spp., } \\
\text { Bacteriodes spp., Alistipes spp., Parabacteroides spp., } \\
\text { Escherichia coli }\end{array}$ & $\begin{array}{l}\text { Yunes et al., } 2016 \text { [70] } \\
\text { Strandwitz et al., } 2019 \text { [71] }\end{array}$ \\
\hline L-glutamate & Glutaminase & $\begin{array}{l}\text { Corynebacterium spp., L. plantarum. L. paracasei, Lactococcus } \\
\text { lactis, L. rhamnosus, Brevibacterium spp., Ruminococcus spp. }\end{array}$ & $\begin{array}{l}\text { Stromeck et al., } 2011[72] \\
\text { Lin et al., } 2013 \text { [73] } \\
\text { Liu et al., } 2017 \text { [74] }\end{array}$ \\
\hline Phenylalanine & $\begin{array}{c}\text { Horismate } \\
\text { mutase/prephenate dehydratase (PheA) }\end{array}$ & Corynebacterium glutamicum Escherichia coli & Ikeda et al., 2006 [75] \\
\hline Tryptophan & Tryptophan synthetase & $\begin{array}{l}\text { Clostridium spp., Pseudomonas spp., Bifidobacterium spp., } \\
\text { Streptomyces spp., C. glutamicum, E. coli, S. typhimurium }\end{array}$ & Ikeda et al., 2006 [75] \\
\hline Kynurenic acid & Kynurenine aminotransferase & E. coli, Pseudomonas spp. & $\begin{array}{l}\text { Han et al., } 2001[76] \\
\text { Sofia et al., } 2018 \text { [77] }\end{array}$ \\
\hline Quinolonic acid & $\begin{array}{l}\text { 3-hydroxyanthranilic acid oxygenase } \\
\text { quinolinate synthase }\end{array}$ & E. coli & Katoh et al., 2006 [78] \\
\hline Indole & Typtophanase & $\begin{array}{c}\text { Clostridium spp. E. coli, Proteus vulgaris, Paracolobactrum } \\
\text { coliforme, Achromobacter liquefaciens, Klebsiella oxytoca, } \\
\text { Providencia stuartii, Citrobacter koseri, M. morganii, } \\
\text { Haemophilus influenza, Stigmatella aurantiaca, Lactobacillus, } \\
\text { B. longum, Bacteriodes fragilis, Parabacteroides distasonis, } \\
\text { Eubacterium hallii }\end{array}$ & $\begin{array}{l}\text { Yanofsky et al., } 1991 \text { [79] } \\
\text { Lee et al., } 2010 \text { [80] }\end{array}$ \\
\hline
\end{tabular}


Table 1. Cont.

\begin{tabular}{|c|c|c|c|}
\hline Metabolite & $\begin{array}{l}\text { Bacterial Enzymes Involved in the } \\
\text { Production of the Metabolite }\end{array}$ & $\begin{array}{l}\text { Microbial Genera and Species Involved in the } \\
\text { Production of the Metabolite }\end{array}$ & Reference \\
\hline Propionic acid & $\begin{array}{l}\text { Propionaldehyde dehydrogenase } \\
\text { methylmalonyl-CoA decarboxylase }\end{array}$ & $\begin{array}{l}\text { Bacteroides spp., Phascolarctobacterium succinatutens, } \\
\text { Dialister spp., Veillonella spp., Megasphaera elsdenii, } \\
\text { Coprococcus catus, Salmonella spp., Roseburia inulinivorans, } \\
\text { Ruminococcus obeum, Dalister succinatiphilus, Eubacterium spp. } \\
\text { (e.g., E. halli), Roseburia spp., Veillonella spp., } \\
\text { Akkermansia muciniphilia, Clostridium spp., Ruminococcus }\end{array}$ & $\begin{array}{c}\text { MacFabe et al., } 2011 \text { [37] } \\
\text { Louis et al., 2014 [81] } \\
\text { Ara Koh et al., 2016 [82] } \\
\text { Markowiak-Kopec et al., 2020 [83] }\end{array}$ \\
\hline Acetic acid & Phosphotransacetylase & $\begin{array}{c}\text { Akkermansia muciniphila, Bacteroides spp., Bifidobacterium } \\
\text { spp., Prevotella spp., Ruminococcus spp., Blautia } \\
\text { hydrogentrophica and Streptococcus spp. }\end{array}$ & $\begin{array}{l}\text { Louis et al., } 2014 \text { [81] } \\
\text { Rey et al., } 2010 \text { [84] }\end{array}$ \\
\hline Butyric acid & Butyrate kinase & $\begin{array}{c}\text { Coprococcus comes, Coprococcus eutactus, Anaerostipes spp., } \\
\text { Coprococcus catus, Eubacterium rectale, Eubacterium hallii, } \\
\text { Eubacterium rectale, Roseburia inulinivorans, } \\
\text { Roseburia intestinalis, Clostridium symbiosum and } \\
\text { Faecalibacterium prausnitzii }\end{array}$ & $\begin{array}{l}\text { Miquel et al., } 2013 \text { [85] } \\
\text { Duncan et al., } 2002 \text { [86] } \\
\text { Louis et al., } 2014 \text { [81] }\end{array}$ \\
\hline Folate & Dihydrofolate synthase & Lactobacillus, Bifidobacterium & Rossi et al., 2011 [87] \\
\hline Pyroxidine & Pyridoxine $5^{\prime}$-phosphate oxidase & Lactobacillus, Bifidobacterium & Gu et al., 2016 [88] \\
\hline Total glutathione & Glutathione synthetase & $\begin{array}{l}\text { Lactobacillus spp., L. lactis, E. coli, Listeria monocytogenes, } \\
\text { enterococci and streptococcus }\end{array}$ & $\begin{array}{l}\text { Fahey et al., } 1991 \text { [89] } \\
\text { Newton et al., } 1996 \text { [90] } \\
\text { Gopal et al., } 2005 \text { [91] }\end{array}$ \\
\hline
\end{tabular}


Table 2. Altered metabolites in patients with depression.

\begin{tabular}{cccc}
\hline \multirow{2}{*}{ Metabolites } & \multicolumn{3}{c}{ Direction of Change in Patient's } \\
\cline { 2 - 4 } Serotonin & Direction of Change & Biosamples & Reference \\
\hline \multirow{2}{*}{ Dopamine } & Decreased & Plasma & $\begin{array}{c}\text { Saldanha et al., 2011 [92] } \\
\text { Pan et al., 2018 [93] }\end{array}$ \\
\cline { 2 - 4 } & Increased & Blood, plasma & Zheng et al., 2016 [94] \\
\hline Noradrenaline & Decreased & Peripheral blood cells & Zhao et al., 2015 [95] \\
\hline GABA & Increased & Blood plasma, urine & Valles-Colomer et al., 2019 [53] \\
\hline \multirow{2}{*}{ L-glutamate } & Decreased & Blood serum & Madeira et al., 2018 [96] \\
\cline { 2 - 4 } & Increased & Cerebrospinal fluid & Inoshita et al., 2018 [97] \\
\hline Phenylalanine & Increased & Peripheral blood & Zheng et al., 2010 [98] \\
\hline Tryptophan & Decreased & Shao et al., 2013 [99] \\
\hline Kynurenic acid & Decreased & Blood plasma & Ogawa et al., 2014 [100] \\
\hline Quinolonic acid & Decreased & Blood plasma and serum & Ogyu et al., 2018 [101] \\
\hline Indole & Increased & Frontal cortex & Bryleva et al., 2017 [102] \\
\hline Propionic acid & Increased & Stool & Skonieczna-Zydecka et al., 2018 [104] \\
\hline Acetic acid & Decreased & Stool & Skonieczna-Zydecka et al., 2018 [104] \\
\hline Butyric acid & Decreased & Stool & Skonieczna-Zydecka et al., 2018 [104] \\
\hline Folate & Decreased & Stool & Bottiglieri et al., 2000 [105] \\
\hline Total glutathione & Decreased & Serum & Gawryluk et al., 2011 [106] \\
\hline
\end{tabular}

\section{Neurotransmitters}

Neurotransmitter imbalance is an almost inseparable feature of depression. The monoaminergic neurotransmitter deficiency hypothesis posits that symptoms of depression arise from insufficient levels of the monoamine neurotransmitters serotonin, noradrenaline, and/or dopamine. Production and release of neurotransmitters are among the numerous functions executed by the GM [107].

\subsection{Serotonin}

Serotonin (5-HT) is a neurotransmitter essential for the generation of emotions. In depression, however, the metabolism and reuptake of 5-HT from the synaptic cleft no longer functions properly. A disrupted serotonergic system has been often cited as one of the causes of depression, impulsivity, and in some cases, suicide. Today, the central role that 5-HT plays in the pathophysiology of depression raises little doubt. This concept is supported by clinical evidence from people affected with depression whose symptoms worsened when their serotonergic system was impaired [108]. Although plasma 5-HT levels do not correlate with 5-HT levels in the brain [109], it is still sensible to study 5-HT in the gut as a biomarker of depression.

Over $90 \%$ of the total amount of $5-\mathrm{HT}$ in the human body is produced in the gut $[43,110]$. One way microbes alter 5-HT levels in the gut is by secreting butyrate, which is known to stimulate 5 -HT synthesis in intestinal enterochromaffin cells (ECs) $[43,110]$. The production of 5-HT was also reported [67] by Candida spp., Streptococcus spp., Escherichia spp. and Enterococcus spp. [68] Hafnia alvei, Klebsiella pneumonia, Lactobacillus plantarum, and Morganella morganii, and others [64-66]. Two metabolic pathways of 5-HT have been identified in bacteria based on whether they are more similar to plants (decarboxylation of TRP to tryptamine followed by hydroxylation) or animals (hydroxylation to 5-hydroxytryptophan and then decarboxylation). The animal-like pathway was more prevalent in the microbial genomes. Although, experimental studies have demonstrated the ability to produce 5-HT for 
approximately 10 genera of gut-dwelling microbes, the presence of these pathways was only confirmed in half of these genera. At the same time, some genera, such as Akkermansia, Alistipes, and Roseburia were only predicted to be able to produce 5-HT based on their genome analysis [53]. The GM can also have a significant impact on 5-HT levels in the body by sequestering tryptophan, the precursor of 5-HT, and converting it to tryptamine, thereby denying the brain its supply of tryptophan, which is much needed for 5-HT production [107,111]. Sterile mice exhibit a significant reduction in 5-HT levels in both plasma and the brain compared to control animals [43]. There is also evidence that the recolonization of the large intestine of germ-free (GF) animals normalizes their 5-HT levels [112].

Despite the fact that depression is mainly treated by serotonin-altering drugs, there is no exhaustive explanation of the underlying mechanism at work. Meanwhile, bacteria have emerged as a new target for depression, as more evidence points to their ability to regulate 5-HT levels in the body.

\subsection{Catecholamines}

Depression has been repeatedly linked repeatedly changes in the catecholamine profile of the body. L-phenylanalnine, the precursor of the main catecholamines, adrenaline, noradrenaline and dopamine, is associated with depression [113]. A study by Chen et al. demonstrated recently impaired metabolism of L-phenylalanine in middle-aged patients with depression [114]. The view of L-phenylalanine metabolism as a biomarker of depression is also supported by animal studies. For instance, rats displaying a depressive-like phenotype as a result of exposure to chronic and mild unpredictable stress were also characterized by lower levels of L-phenylalanine [98,99]. It should perhaps be noted that L-phenylalanine was one of the metabolites used to differentiate responders from nonresponders to medication [115]. Biosynthetic pathways of L-phenylalanine in bacteria were described in Corynebacterium glutamicum and Escherichia coli in the review of Ikeda [73].

Furthermore, individuals with bipolar and unipolar depression were marked by increased levels of noradrenaline in the blood plasma and urine [95]. Many metabolomic analyses have also reported altered dopamine levels in depression. For instance, Pan et al. asserted that dopamine plasma levels in patients with depression were higher [93], while the results of Zheng et al. reported lower dopamine levels in peripheral blood cells [94]. Dopamine is the primary neurotransmitter in the reward pathway [116] and the driver of motivated behavior. It is also involved in motor functions and the regulation of cognitive processes [117]. Aberrant functioning of the dopaminergic system is associated with anhedonia, one of the key symptoms of depression [116]. Moreover, depression is characterized by an underactive dopaminergic system. This could be due to weak binding of the dopamine transporter as concluded in a study of the brains of patients with depression using a PET scan [118]. Further evidence bringing the dopaminergic system and depression closer together comes from interventional studies. While pharmacological treatment aimed at blocking or lowering dopamine levels aggravate the symptoms of depression [119], some dopamine agonists can mimic the effects of antidepressants [120]. Moreover, some antidepressants, such as buprapion and venfloxacin, possess dopamine reuptake activity $[119,121]$, and there is a correlation between the positive effects of transcranial magnetic stimulation and blood levels of homovanillic acid-the main metabolite of dopamine [122].

Animal studies also show a clear link between the dysfunction of the dopamine system and depressive-like behavior [123]. For example, stress-mediated changes in the hippocampus and PFC of rodents have been suggested to reduce the release of dopamine and induce anhedonia. D-2 receptor agonists exhibit therapeutic effects in animals. Chronic treatment with quinpirole and bromocriptine mimicked the behavioral effects of antidepressants in the sucrose consumption model [124].

Since the GM regulates the activity of many brain regions, including those related to the mesocorticolimbic system [125], it is well-founded that the dopamine system does not function independently from the GM. Such communication occurs via the hypothalamic-pituitary-adrenal axis [126], the immune system [127], and the vagus nerve [128,129]. Stimulation of the vagus nerve in the intestinal tract increases the release of dopamine in the brain [130]. Not only do some members of the 
GM affect the host organism by synthesizing catecholamines, but by doing so, they regulate the growth of other bacteria as well [107]. Dopamine, for instance, is produced by Bacillus, Serratia, Lactobacillus, Klebsiella, Morganella [45], and Escherichia coli [64]. In addition, the growth of enterohemorrhagic E. coli O157: H7 is stimulated by noradrenaline and dopamine [131].

Thus, since the influence of symbiotic microorganisms on the dopamine system is obvious, and based on the latter being considered one of the organic manifestations of depression, we can draw a line between the GM and depression.

\section{3. $G A B A$}

One of the neurotransmitters robustly associated with anxiety and depression besides 5-HT and dopamine, is gamma aminobutyric acid (GABA), the major inhibitory neurotransmitter in the mammalian CNS. GABA levels were found to be decreased in the blood serum of about one-third of patients with MDD, as well as in patients with mania and bipolar patients [53].

GABA owes its sedative action to its ability to bring a nerve impulse to a halt by binding to GABAergic receptors in the CNS. Transmembrane GABAergic receptors are located in the chemical synapses throughout the autonomic and central branches of the nervous system and in various tissues and organs of the human body (intestines, stomach, pancreas, kidneys, lungs, liver, and others). $\mathrm{GABA}_{\mathrm{B}}$ receptors receive special attention in depression as they were recognized as one of the main targets of the disease [132]. For instance, benzodiazepines, which are prominently known to increase the affinity between GABA and its receptors, have been widely used as antidepressants. Animal studies show that a decrease in $\mathrm{GABA}_{B}$ receptors is associated with depressive-like behavior. Nevertheless, the use of $\mathrm{GABA}_{B}$ antagonists rather than the agonist baclofen was proven more effective for treating depression $[133,134]$. The absence of $\mathrm{GABA}_{\mathrm{B}}$ receptors, as demonstrated in knockout mice, has been shown to have favorable effects [135]. Inconsistency in this field could arise from the fact that the two isoforms of $G_{A B A}$ receptors sometimes elicit contradictory results. The implication of $G_{A B A}$ receptors in depression is strongly believed to be related to their role in influencing the serotoninergic pathway [136]. Most cell bodies of neurons in the raphe nuclei express $G_{A B A}$ receptors and were shown to react to baclofen by increasing their fire rate and thereby the release of 5-HT. Intake of L. rhamnosus altered the central mRNA expression of $\mathrm{GABA}_{\mathrm{A}}$ and $\mathrm{GABA}_{\mathrm{B}}$ receptors while reducing depressive and anxiety-like behavior in mice. The major contribution of this study was that it elegantly proved that $L$. rhamnosus produced the mentioned effects via the vagus nerve [129].

The data from several studies suggest that the GM does contribute to blood GABA levels. For instance, in mice with a disrupted GM, one of the many altered metabolites in the blood in consequence was GABA [137]. It is known that bacteria, such as Lactobacillus and Bifidobacterium, can synthesize GABA from dietary glutamate. Lactobacillus rhamnosus has been shown to reduce anxiety and depressive behavior while increasing GABA levels in the hippocampus [49]. Bacteroides spp. produce large quantities of GABA. Transcriptome analysis of stool from healthy individuals showed that the pathways of GABA production are actively expressed by Bacteroides, Parabacteroides, and Escherichia species. A recent study combining $16 \mathrm{~S}$ rRNA sequencing with fMRI imaging, found a negative correlation between the abundance of fecal Bacteroides and the default mode network in the brains of patient with MDD [71]. Interestingly, Bacteroides spp., and to a lesser extent Parabacteroides spp., produce GABA within the near-neutral $\mathrm{pH}$ range of the human large intestines. In silico analysis predicted that at least 97 microorganisms possessed the ability to produce GABA, mostly using the enzyme glutamate decarboxylase. More than 25\% belonged either to the genera Bacteroides or Parabacteroides. Moreover, the study identified 102 microorganisms that potentially consume GABA as a source of energy. The majority of those species belonged to the genera Pseudomonas, Acinetobacter, and Mycobacterium [71].

Bacteria produce gamma-aminobutyric acid via the enzyme glutamate decarboxylase, which irreversibly decarboxylates L-glutamic acid [138]. The gene encoding the enzyme glutamate decarboxylase, gadB, was identified in the genomes of many bacterial species, including those 
of bifidobacteria and lactobacilli. After decarboxylating L-glutamic acid, the gadB gene requires an antiporter, encoded by gadC and usually located in its proximity, to excrete GABA through the bacterial wall [70].

In the intestinal tract, microbial-derived GABA can trigger the release of other neurotransmitters from epithelial cells [42]. GABA also regulates the expression of proinflammatory interleukins by binding to various types of immune cells expressing GABA receptors, which makes it involved in immunomodulation [139]. Based on ligand-based in vivo studies, it has been inferred that GABA in the gut acts as a regulator of secretory and motor activities with an anti-inflammatory effect [139]. Microbe-derived GABA can cross the intestinal barrier via H+/GABA symporter [140] and subsequently interact with GABA receptors and transporters that are widely expressed on enteric neurons and vagus afferents [141].

\subsection{Glutamate-Glutamine Cycle}

Glutamate (GLU) is the primary and most abundant excitatory neurotransmitter in the CNS. Glutamatergic activity in the brain is dictated by the degradation of glutamine to GLU as a part of the glutamate-glutamine cycle. Thus, the glutamate-glutamine cycle is crucial for normal glutaminergic neurotransmission. A dysregulated glutamatergic system is viewed as one of the biological underpinnings of depression [142].

The role of GLU is central to the neuroplasticity hypothesis of depression [143]. Many animal models are grounded on the premise that depression could be explained in terms of disturbances of brain glutamatergic pathways [144,145]. Zhang et al. reported that the expression of the excitatory amino acid transporter 2 (EAAT2), the major glutamate transporter in the mammalian brain was upregulated, which is consistent with studies of postmortal brain samples from patients with depression $[142,146]$ and the biological basis of the learned helplessness theory of depression [147]. EAAT2 is a key membrane transporter in glial cells that plays an important role in the glutamate/glutamine cycle [148], which is indispensable for the communication between glia and neurons [149]. In patients with depression, GLU and glutamine levels in the cerebrospinal fluid are increased compared to healthy controls [96]. Moreover, the therapeutic effects of cytidine in patients with bipolar depression were ascribed to its ability to decrease glutamine/glutamate levels in the brain [150]. A prior meta-analysis of 12 association studies had reported increased plasma GLU levels in patients with MDD [97].

There could be an indirect link between glutamatergic transmission in the ENS and depression. The high incidences of inflammatory bowel syndrome among patients with depression imply that depression could originate in the gut [151]. Thus, disruption of glutamatergic transmission in the ENS, a major regulator of motor and secretory regulator, could be one of the factors accounting for inflammatory bowel syndrome. A large-scale metagenomic-wide association study of 1070 individuals affected with depression revealed that depleted GLU degradation genes in the microbiota were associated with depression [53].

Bacteria can alter the GLU luminal and plasma levels in many ways. Most bacteria consume GLU and use it in the Krebs cycles to generate energy. Besides consuming it, some synthesize GLU as a by-product of fermentation [152]. Moreover, the production of GLU is not restricted to prokaryotic cells but extends to epithelial cells as well. Based on this information, we can conclude that GLU is a common currency in the mammalian body. The GLU-consuming bacterium B. thetaiotaomicron, reduced GLU levels in both plasma and the gut [74]. Unsurprisingly, a correlation has been found between circulating GLU and glutamine plasma levels and certain bacteria of the genus Ruminococcus possessing the necessary genetic machinery to convert glutamine to GLU [74]. Moreover, Corynebacterium glutamicum, Brevibacterium lactofermentum, and Brevibacterium avium, convert L-glutamate into D-glutamate, and use it as a building block of their peptidoglycan cell wall. Bacteria carry out this reaction using the glutamate racemase MurI [153]. Bacteroides vulgatus and Campylobacter jejuni were shown to affect GLU metabolism by decreasing 2-keto-glutaramic acid levels. L. rhamnosus produced GABA and GLU in vitro using glutamate decarboxylase and glutaminase, respectively [72,74]. These biosynthetic machineries 
utilized by microbes to synthesize GLU and GABA are identical in neurons [154], which support the interkingdom communication of microbial GABA [155].

One of the main discoveries in understanding the mechanism of depression is the identification of dysfunction in neurotransmission. Gut bacteria directly or indirectly can affect the content of serotonin, catecholamines, GABA, etc., and modulate the functioning of neurotransmitter systems, taking a possible role in the pathogenesis of depression. Therefore, such bacteria as biomarkers of depressive disorders can be used in clinical practice as part of the complex diagnostic systems for the analysis of the GM.

\section{Amino Acids as Biomarkers of Depression}

Gut bacteria play an important role in host amino acid (AA) homeostasis through multiple pathways. Metabolic interactions of AAs exist across a large number of gut bacterial species. Such interactions occur between bacteria and the host either at the local level (mucosal cells), systemic level (whole body) or even within different compartments of the intestine. Gut bacteria devised multiple strategies to survive in the intestine by modulating their AA metabolic pathways. Studies over the last decades have shown that gut bacteria can affect the physiology and metabolism of their neighboring species and eukaryotic host through the synthesis of a wide variety of AAs and their metabolites.

Since an aberration of AA metabolism has been associated with depression, many studies focused on finding the concrete AAs that could be used as biomarkers. Table 3 presents an overview of studies focusing on AA levels in animals and patients. According to a clinical study, blood levels of serine, methionine, asparagine, glutamine, and tryptophan (TRP) were decreased in patients with depression [156]. Another study determined that patients with depression had elevated plasma levels of phenylalanine, aspartate, serine, and $\gamma$-glutamyl AAs ( $\gamma$-glutamyl leucine and $\gamma$-glutamyl glutamine) $[113,149]$. AA metabolites involved in the synthesis of branched-chain AAs, namely leucine, isoleucine, threonine and methionine, were also found to be dysregulated in patients with MDD [157].

Animal studies demonstrated that AA blood levels are influenced by the GM and are linked to depression, too. Analysis of the fecal metabolome of rats exhibiting depressive-like behavior revealed changes in the levels of the AAs L-threonine, isoleucine, alanine, serine, tyrosine, and oxidized proline. Interestingly, changes in plasma AA levels correlated with both the phylogenetic composition and changes in the AA levels observed in the fecal metabolome. A conclusion can be drawn, tying AA metabolism in the GM to an altered AA profile in the blood circulation, which can lead to behavioral changes in the characteristics of depression [158].

Metabolites of arginine catabolism are considered relevant to depression. Many studies highlighted the antidepressant and anxiolytic effects of putrescine and agmatine, a naturally occurring chemical through decarboxylation of arginine. Table 4 highlights the studies where the antidepressant and anxiolytic effects of AAs were shown. These AAs are likely to act as inhibitors of nitric oxide synthase and blockers of $\mathrm{N}$-methyl-D-aspartate receptors, which make them promising candidates for future drugs. [159]. Decreased L-arginine levels in depressed patients could account for the decrease in NO metabolites [160]. In the study carried out by Lu et al. decreased plasma levels of aspartate, GLU and GABA, as well as increased levels of NO, were suggested as biomarkers of a melancholic form of MDD [161]. 
Table 3. Amino acid levels in animal models and patients with depression.

\begin{tabular}{|c|c|c|c|c|c|}
\hline Amino Acids (AA) & & AA Levels in Animal Models of Depression & & AA Plasma Content & Patients with Depression \\
\hline \multirow{4}{*}{ Alanine } & Direction of Change & Biosamples, Animal Model & Reference & Direction of Change & Reference \\
\hline & Decreased & PFC, rat, learned helpfulness model & Zhou et al., 2017 [162] & \multirow{4}{*}{ Increased } & \multirow{4}{*}{ Mitani et al., 2006 [163] } \\
\hline & Decreased & Feces, rat, chronic unpredictable mild stress model & Jianguo et al., 2019 [158] & & \\
\hline & Decreased B-alanine & $\begin{array}{l}\text { Mononuclear blood cells, rat, chronic unpredictable } \\
\text { mild stress model }\end{array}$ & Li et al., 2014 [164] & & \\
\hline Arginine & Decreased & Urine, rat, olfactory bulbectomy model & Zhou et al., 2019 [165] & & \\
\hline Asparagine & $\begin{array}{c}\text { Abnormalities of } \\
\text { arginine metabolism }\end{array}$ & Plasma, urine, rat, excess fatigue & Zhang et al., 2010 [166] & Decreased & Hess et al., 2017 [160] \\
\hline Aspartate & Increased & Urine, rat, chronic unpredictable mild stress model & Liu et al., 2012 [167] & Decreased & Pu et al., 2020 [156] \\
\hline \multirow{2}{*}{ GABA } & \multirow{2}{*}{ Decreased } & \multirow{2}{*}{$\begin{array}{l}\text { Mononuclear blood cells, rat, chronic unpredictable } \\
\text { mild stress model }\end{array}$} & \multirow{2}{*}{ Li et al., 2014 [164] } & Increased & Steffens et al., 2010 [113] \\
\hline & & & & Decreased & Lu et al., 2014 [161] \\
\hline Glutamic acid & Decreased & PFC, rat, learned helpfulness model & Zhou et al., 2017 [162] & Decreased & Lu et al., 2014 [161] \\
\hline Glutamine & Decreased & $\begin{array}{l}\text { Mononuclear blood cells, rat, chronic unpredictable } \\
\text { mild stress model }\end{array}$ & Li et al., 2014 [164] & Increased & Inoshita et al., 2018 [97] \\
\hline \multirow{2}{*}{ Glycine } & Decreased & PFC, rat, learned helpfulness model & Zhou et al., 2017 [162] & \multirow{2}{*}{ Decreased } & \multirow{2}{*}{$\begin{array}{l}\text { Pu et al., } 2020 \text { [156] } \\
\text { Lu et al., } 2014 \text { [161] }\end{array}$} \\
\hline & Increased & Urine, rat, chronic unpredictable mild stress model & Liu et al., 2012 [167] & & \\
\hline \multirow[t]{2}{*}{ Isoleucine } & Decreased & $\begin{array}{l}\text { Mononuclear blood cells, rat, chronic unpredictable } \\
\text { mild stress model }\end{array}$ & Li et al., 2014 [164] & \multirow[t]{2}{*}{ Increased } & \multirow[t]{2}{*}{ Mitani et al., 2006 [163] } \\
\hline & Increased & Urine, rat, chronic unpredictable mild stress model & Liu et al., 2012 [167] & & \\
\hline Leucine & Decreased & Feces, rat, chronic unpredictable mild stress model & Jianguo et al., 2019 [158] & Decreased & Baranyi et al., 2016 [157] \\
\hline Methionine & Increased & Urine, rat, olfactory bulbectomy model & Zhou et al., 2019 [165] & Decreased & Baranyi et al., 2016 [157] \\
\hline Phenylalanine & Decreased & PFC, rat, learned helpfulness model & Zhou. et al., 2017 [162] & Decreased & $\begin{array}{c}\text { Pu et al., } 2020 \text { [156] } \\
\text { Baranyi et al., } 2016[157]\end{array}$ \\
\hline
\end{tabular}


Table 3. Cont

\begin{tabular}{|c|c|c|c|c|c|}
\hline \multirow{2}{*}{ Amino Acids (AA) } & \multicolumn{3}{|c|}{ AA Levels in Animal Models of Depression } & \multicolumn{2}{|c|}{ AA Plasma Content in Patients with Depression } \\
\hline & Direction of Change & Biosamples, Animal Model & Reference & Direction of Change & Reference \\
\hline \multirow{2}{*}{ Proline } & Increased & Serum, rat, chronic unpredictable mild stress model & Xiong et al., 2016 [168] & Increased & Steffens et al., 2010 [113] \\
\hline & Decreased & PFC, rat, learned helpfulness model & Zhou et al., 2017 [162] & - & - \\
\hline \multirow[t]{2}{*}{ Serine } & $\begin{array}{l}\text { Decreased oxidized } \\
\text { proline }\end{array}$ & Feces, rat, chronic unpredictable mild stress model & Jianguo et al., 2019 [158] & Increased & Hashimoto et al., 2016 [169] \\
\hline & Decreased & Feces, rat, chronic unpredictable mild stress model & Jianguo et al., 2019 [158] & Decreased & Pu et al., 2020 [156] \\
\hline Threonine & Decreased & Feces, rat, chronic unpredictable mild stress model & Jianguo et al., 2019 [158] & Decreased & Baranyi et al., 2016 [157] \\
\hline \multirow{2}{*}{ Tryptophan } & Increased & PFC, rat, olfactory bulbectomy model & Zhou et al., 2019 [170] & \multirow{2}{*}{ Decreased } & Pu et al., 2020 [156] \\
\hline & Decreased & Serum, rat, chronic unpredictable mild stress model & Xiong et al., 2016 [168] & & Myint et al., 2007 [171] \\
\hline Tyrosine & Decreased & Feces, rat, chronic unpredictable mild stress model & Jianguo et al., 2019 [158] & Decreased & Islam et al., 2020 [172] \\
\hline $\begin{array}{c}\gamma \text {-glutamyl leucine } \\
\text { and } \gamma \text {-glutamyl } \\
\text { glutamine }\end{array}$ & - & - & - & Increased & Hashimoto et al., 2016 [169] \\
\hline
\end{tabular}


Table 4. Antidepressant and anxiolytic effects of AAs in preclinical and clinical settings.

\begin{tabular}{|c|c|c|c|}
\hline Amino Acids & Type of Study & Effects & Reference \\
\hline Alanine & Rodent model of acute stress & $\begin{array}{l}\text { Elicited an anxiolytic-like effects in the elevated plus maze } \\
\text { Decreased the concentration of 5-hydroxyindoleacetic } \\
\text { acid et al., a major metabolite of serotonin et al., in the } \\
\text { hypothalamus } \\
\text { Increased carnosine beta-alanyl-L:histidine concentration in } \\
\text { the cerebral cortex and hypothalamus } \\
\text { Increased brain-derived neurotrophic factor levels in the } \\
\text { hippocampus }\end{array}$ & Murakami et al., 2010 [173] \\
\hline Arginine & Rat model of chronic mild stress-induced depression. & $\begin{array}{l}\text { Increased the sucrose preference ratio } \\
\text { Increased locomotor activity } \\
\text { Increased monoamines } \\
\text { Decreased serum cortisol and NO levels } \\
\text { Increased BDNF mRNA expression }\end{array}$ & Dong et al., 2020 [174] \\
\hline Glutamine & Rodent model of immobilization stress & Increased glutamatergic neurotransmission & Son et al., 2016 [175] \\
\hline Leucine & Murine model of inflammation-induced depression & $\begin{array}{l}\text { Antidepressant-like effects on behavior } \\
\text { Decreased brain kynurenine levels }\end{array}$ & Walker et al., 2019 [176] \\
\hline Methionine & $\begin{array}{l}\text { Comprehensive review of the efficacy of } \\
\text { S-adenosyl-L-methionine in MDD }\end{array}$ & $\begin{array}{l}\text { Effective in patients nonresponsive to selective serotonin } \\
\text { reuptake inhibitors and serotonin-norepinephrine } \\
\text { reuptake inhibitors }\end{array}$ & De Berardis et al., 2016 [177] \\
\hline \multirow{2}{*}{ Serine } & Murine model & $\begin{array}{l}\text { D-serine administration significantly reduced immobility in } \\
\text { the forced swimming test }\end{array}$ & Malkesman et al., 2012 [178] \\
\hline & Srrtg transgenic mice & $\begin{array}{l}\text { Elevated brain D-serine levels and reduced proneness } \\
\text { towards depression-like behavior }\end{array}$ & Otte et al., 2013 [179] \\
\hline Tryptophan & Patients & Improved mood & Muszyńska et al., 2015 [180] \\
\hline Tyrosine & Rats fed L-tyrosine-loaded nanoparticles. & $\begin{array}{l}\text { Decreased the immobility time in the FST et al., } \\
\text { concomitant with restoration of the basal levels of } \\
\text { locomotor activity, distance travelled and rearing counts } \\
\text { Increased sucrose consumption }\end{array}$ & Alabsi et al., 2016 [181] \\
\hline
\end{tabular}


Isoleucine plays a crucial role in the mammalian CNS. Isoleucine is transported across the blood-brain barrier to the brain where it is used as the main amino group donor for GLU synthesis [182]. A study conducted by Baranyi et al. reported reduced isoleucine levels in depressed patients infected with hepatitis $\mathrm{C}$ compared to non-depressed HCV-infected patients. The same authors pointed out that isoleucine is a potential immunosuppressant, which is well aligned with the inflammatory hypothesis of depression [183].

TRP is the precursor for $5-\mathrm{HT}, 90 \%$ of which is produced in the gut and $10 \%$ in the brain [184]. Only a small percentage (1-3\%) of dietary TRP crosses the blood-brain-barrier into the brain, where it is converted into 5-HT. Today, the conventional view is that the balance between the pathways of TRP metabolism in the body is one of the factors contributing to the body's predisposition to depression. Patients with higher depression scores may have reduced plasma levels of L-tryptophan [171]. Low blood TRP levels amount to less 5-HT synthesis in the brain. Certain microbial species have been shown to increase plasma TRP levels. As experiments on GF animals show, the GM affects TRP availability in the body, thereby decreasing 5-HT levels in the brain [20]. Plasma TRP levels in GF animals are significantly higher than in conventional animals, most likely because the GM is involved in TRP metabolism. This hypothesis is supported by much evidence from studies of the effects of microbial colonization of GF animals, which induced the expression of many enzymes involved in TRP metabolism [185]. Changes in TRP metabolism were also seen in animals with transplanted microbiota of patients with depression.

The amount of intestinal TRP, which is not transferred to the systemic circulation after absorption, may be locally transformed by different gut microbial species into many catabolites via various metabolic pathways. In the Firmicutes phylum, Clostridium sporogenes, and Ruminococcus gnavus convert TRP into tryptamine, a biogenic amine structurally similar to 5-HT, using tryptophan decarboxylases [111]. Tryptamine-producing Ruminococcus gnavus is a common species of the GM found in around $90 \%$ of adults [186] and infants [187]. This is all the more interesting since tryptamine has an important role in maintaining gut homeostasis. Endogenous TRP is another well-studied microbiota-related metabolite.

Many gram-positive and gram-negative bacteria produce indole, which led some authors to suggest that indole is an important signaling molecule affecting both bacterial and human physiology [80]. An indolic compound is produced by the enzyme tryptophanase expressed in a large number of microorganisms, including Escherichia coli, Proteus vulgaris, Paracolobactrum coliforme, Achromobacter liquefaciens, and Bacteriodes spp. and possesses three permeases for TRP transport and produces indole metabolites as by-products of the amino acid metabolism to obtain carbon and nitrogen [79]. Excessive amounts of indole produced by the GM have been shown to increase anxiety-like and depression-like behavior in rats. In a more recent study, indole was linked to the vulnerability of mice exposed to chronic mild stress and interfered with catecholamine biosynthesis in the adrenal medulla [188]. Microbial indole triggered enteroendocrine L-cells to produce glucagon-like peptide 1 (GLP-1), which in turn stimulated colonic vagal afferent activity [189]. The administration of Isatin, an indole derivative seen as a neuroprotective agent, to mice altered the expression of many genes as well as the proteome in their brains [190]. Indole-3-lactic acid, which is another indole derivative produced by lactobacilli and bifidobacteria [191], exerted an enhancing effect on neuron differentiation in PC12 cells via AhR receptors [192]. Indole-3-propionic acid (IPA) is a very powerful antioxidant molecule, produced by Clostridium sporogenes, which had gained much attention related to its great potential in protecting the organism against oxidative stress (OS) [193], reducing inflammation [194], and even treating neurodegenerative diseases due to its ability to attenuate endoplasmic reticulum stress, thereby preventing neuronal cell death [195]. Clostridia, Bifidobacteria and Bacteroides spp. metabolize TRP into indole-3-acetic acid (IAA) via multiple pathways, one of which requires a prior transformation of TRP to IPA, and another one including other intermediary molecules such as tryptamine and indole-3-acetaldehyde [196]. IAA is also a plant hormone used by many endophytic bacteria for various purposes $[197,198]$. The impact of IAA on health has only been addressed in one 
study where it was associated with cognitive impairment in hemodialysis patients [199]. Indole has many derivatives, whose impact on the CNS is yet to be fully unveiled.

The tryptophan-kynurenine pathway is one of the more diverse pathways of AA metabolism. The products of this pathway encompass both the neuroprotective kynurenic acid and the neurotoxic 3-hydroxykynurenine and quinolinic acid metabolites. Decreased levels of kynurenic acid have been associated with increased neurotoxicity in depression. The heightened levels of quinolinic acid in the frontal cortex are associated with an elevated suicide risk in mood disorder patients [102]. Depression is sometimes explained in terms of an aberrant KYN/TRP pathway [200]. An elevated ratio of plasma KYN/TRP often correlates positively with depression severity in humans [181,201]. A number of meta-analyses reported decreased levels of TRP, kynurenic acid, and kynurenine and increased GLU levels, in MDD patients [97,100,101].

Patients with depression are marked by an increased activity of key enzymes involved in TRP catabolism, tryptophan 2,3-dioxygenase, and indodelamine 2,3-dioxygenase [202]. As a consequence, TRP is metabolized before reaching the brain, which explains why low plasma TRP levels are common in affective disorders [202,203].

D-serine is one of many amino acids exerting antidepressant effects as attested by animal studies conducted in rodent models of depression. $[178,179]$. The mode of action of D-serine is likened to that of ketamine. [204]. D-serine may be an indicative biomarker of the antidepressant response to ketamine [205].

Leucine also exhibits antidepressant-like effects in mice accompanied by a reduction in brain kynurenine levels [176]. The protective effects of leucine against inflammatory-induced depression are ascribed to its ability to block kynurenine from entering the brain [206].

The main members of the GM that are known to produce AAs are: Streptococcus spp., Staphylococcus aureus, Escherichia coli, Klebsiella spp., Selenomonas ruminantium, Megasphaera elsdenii, Prevotella spp., Bacteroides spp., and Clostridium spp. [207].

Bacteria of the genus Pseudomonas possess two genes involved directly in the conversion of TRP into kynurenine, namely KynA and KynB, which encode the enzymes TDO and kynurenine formamidase, respectively [208]. E. coli have been shown to produce kynurenic acid from kynurenine due to the enzyme aspartate aminotransferase possessing kynurenine aminotransferase activity [76]. Other enzymes that allow E. coli to synthetize quinolonic acid from aspartate are aspartate oxidase and quinolinate synthase [78].

AAs such as glutamine/glutamate, asparagine/aspartate, lysine, serine, threonine, arginine, glycine, histidine and branched-chain AAs might be more readily degraded by gut bacteria [207].

AAs are implicated in almost all the biochemical reactions taking place in the human body. Therefore, AA imbalance is a potential determinant of various diseases, including mental disorders. AAs also play a key role in the metabolic pathways of bacteria, which makes them involved in the interplay between the gut and the brain. Some AA and their metabolites of bacterial origin can be considered as biomarkers of depression in clinical practice.

\section{SCFAs as Biomarkers of Depression}

Some of the most important bacterial metabolites mediating the communication between the gut and the brain are SCFAs. Bacteria produce SCFAs as a byproduct of the fermentation of non-digestible carbohydrates [209]. The resulting end products include acetate, propionate, and butyrate [210] and, to a lesser extent, iso-butyrate, valerate and iso-valerate [187]. The lipophilic nature of SCFAs allows them to easily reach the brain by crossing the blood-brain-barrier, where they interact with neurons. Conversely, the salubrious properties of SCFAs could emerge from their strengthening properties of the intestinal barrier, the major crossing point of molecules and nutrients from the bloodstream to the brain. Although the exact mechanisms of action of SCFAs are not completely clear, their therapeutic potential for treating neurological and neurodegenerative disorders is widely supported by animal studies [211]. SCFAs activate G-protein coupled receptors located on endocrine and immune cells, 
kidneys, blood vessels, and nerve cells. SCFAs exhibit anti-inflammatory properties, and low SCFA levels characteristic of a "dysbiotic" GM could be one of the causes of inflammation in depression

Many animal studies have confirmed the antidepressant effects of SCFAs, directly or indirectly. For instance, the transplantation of fecal microbiota from patients with depression to sterile rats made them anxious and increased fecal SCFA levels compared to rats receiving donor microbiota from healthy individuals [49]. In an animal model of mania, the administration of sodium butyrate, a major SCFA, restored normal levels of activity and mitochondrial function in the PFC, hippocampus, striatum, and amygdala [212]. Sodium butyrate also abrogated depressive-like and mania-like behavior in rats [213].

Acetic, propionic, and caproic acids have been shown to partly contribute to the origin of symptoms of depression through the MGBA. Acetate exerts protective activity against enteropathogenic infections and fortifies the gut barrier. Lower levels of acetate observed in patients with depression translate into a decrease in butyric acid. Propionate dampens the innate immune cell response to bacteria, and may also be involved in keeping intestinal permeability in check $[127,214]$. Lower levels may contribute to dysbiosis and neuroinflammation in the CNS, which are known risk factors for depression. In the study by El-Ansary et al. the administration of propionate to animals was followed by changes in their phospholipid and acylcarnitine profiles. Besides its direct effect on the brain, propionate modulates the secretion of 5-HT in the gastrointestinal system and causes a decline in brain 5-HT and dopamine levels $[215,216]$. Oral administration of propionate induced lipid peroxidation in rodents and led to a decreased activity of glutathione, glutathione peroxidase and catalase [217]. In the study of Skonieczna-Zydecka, acetate and propionate levels correlated inversely with the symptoms of depression, as evaluated with the Beck depression inventory. Fecal levels of isocaproic acid were significantly lower in Polish women with depression [104].

According to a study of the effects of butyrate on behavior, memory, and levels of neurotrophic factors in a rat model of chronic mild stress, butyrate functions as an antidepressant [218]. Aside from regulating the levels of neurotrophic factors, butyric acid typically inhibits histone deacetylation and prevents hippocampal microglia activation. Bacteria-derived butyrate has been shown to modulate the synthesis of dopamine, noradrenaline, and adrenaline by altering the expression of the tyrosine hydroxylase-encoding gene [219].

Isovaleric acid is another SCFA that was found to be correlated with the symptoms of depression and blood levels of cortisol [54]. Isovaleric acid interferes with the release of neurotransmitters into the synaptic cleft, which implies a causal relationship between it and depression. For instance, isovaleric acid levels in the colon can directly impact the functioning of the hypothalamus in the brain [54]. Understandably, bacteria capable of altering the levels of valeric acid in the gut are an interesting target for treating depression. Valeric acid, due to its structural similarity to GABA, acts as an inverse agonist of the adenosine A1 receptor in the brain, which is known for its role in the regulation of neurotransmitter release [54].

The genera of enteric bacteria that contribute to acetic acid production are Akkermansia muciniphila, Bacteroides spp., Bifidobacterium spp., Prevotella spp., Ruminococcus spp., Blautia hydrogentrophica, and Streptococcus spp. [81,84].

The organism's supply of butyrate is exclusively derived from butyrate producing bacteria, which include: Coprococcus comes, Coprococcus eutactus, Anaerostipes spp., Coprococcus catus, Eubacterium rectale, Eubacterium hallii, Eubacterium rectale, Roseburia inulinivorans, Roseburia intestinalis, Clostridium symbiosum, and Faecalibacterium prausnitzii $[81,85,86]$.

The bacterial genera and species involved in propionic acid production are the following: Bacteroides spp., Phascolarctobacterium succinatutens, Dialister spp., Veillonella spp., Megasphaera elsdenii, Coprococcus catus, Salmonella spp., Roseburia inulinivorans, Ruminococcus obeum, Dalister succinatiphilus, Eubacterium spp. (e.g., E. halli), Roseburia spp., Veillonella spp., Akkermansia muciniphilia, Clostridium spp., and Ruminococcus spp. [220].

The production of valeric acid was associated with the genera Acidobacteria, Paracoccus denitrificans [221]. 
Faecal proteolytic bacteria Propionibacteriurn spp., Clostridium spp., Streptococcus spp., Bacillus spp. and Staphylococcus spp. [222] can extract iso-butyric and iso-valeric acid from proteins.

Since SCFAs are bacterial metabolites, their levels in the body completely depend on the GM composition. Existing studies that reveal the potential of SCFA as biomarkers of depression confirm the correlation of the gut bacteria with the pathogenesis of the disease. This may potentially expand the diagnostic criteria for depressive disorders in clinical practice.

\section{Other Bacterial Metabolites as Biomarkers of Depression}

Since depression was formulated as a mental illness, many studies have focused on identifying potential blood-based biomarkers [223,224]. MDD patients were characterized by higher levels of asymmetric dimethylarginine, tyramine, 2-hydroxybutyric acid, phosphatidylcholine (32:1), and taurochenodesoxycholic acid and lower levels of L-acetylcarnitine, creatinine, linoleic acid, pyruvic acid, palmitoleic acid, oleic acid, myo-inositol, dodecanoic acid, hypoxanthine, palmitic acid, taurine, 25-hydroxyvitamin D [225].

A recent study raised the question of the relevance of vitamin B intake in the light of the negative correlation between it and the symptoms of depression [226,227]. Interestingly, gut bacteria are an important source of B-vitamins, namely, niacin (B-3), biotin (B-7), folate (B-9), and pyroxidine (B-6) $[228,229]$. Biotin and niacin, in particular, participate in immunomodulation, and deficiency of these vitamins could be one of the reasons of gut and systemic inflammation [230]. Folate levels in the serum of patients with depression are lower than those of controls [105] and may be associated with symptom severity [231] and responsiveness to antidepressant treatment [232]. Folic acid is another product of bacterial metabolism that correlates with symptoms of depression [233]. Folate deficiency is diagnosed in one in three patients with depression. The main folate-producing bacteria belong to species of Lactobacillus and Bifidobacterium [87]. Pyroxidine, an essential cofactor for many enzymes participating in the kynurenine pathway, is altered in patients with depression [171]. Lactobacillus and Bifidobacterium, as well as other gut bacteria, synthesize B-group vitamins and vitamin $\mathrm{K}$ as part of their core metabolic pathways in the large intestine, and humans rely heavily on the GM as a source of these vitamins [88].

Polyunsaturated fatty acids (PUFAs) are involved in the structural and functional regulation of neurons, glial cells and endothelial cells in the brain, which makes them strongly linked to depression. A recent study has linked inflammation to PUFAs, more specifically with their metabolites [234]. Druart et al. demonstrated the GM's ability to transform dietary PUFAs into other molecules, pointing out that these metabolites could be of bacterial origin [235]. A comparison of the ratio of PUFA-derived metabolites and the expression of fatty acid desaturases between GF and conventionalized mice revealed higher concentrations of PUFA-derived metabolites in the colonic contents of conventionalized mice. Omega-3 PUFAs are known to modulate the GM composition [236]. Mice fed an omega-3-enriched diet exhibited significantly enhanced cognition, and attenuated HPA-axis activation and inflammation, as well as an improved intestinal epithelial integrity, possibly due to a higher abundance of bifidobacteria [237].

$\mathrm{N}$-acetyl aspartate (NAA), a marker of neuron vitality, was found to be decreased in the prefrontal cortex (PFC) and hippocampus of MDD patients [238,239]. Oral administration of L. rhamnosus to mice increased NAA, Glx and GABA levels in the PFC and the hippocampus [240], implicating antidepressive potential of bacterium.

Fatty acids, through their effects on cell membrane structure, biological stress, and inflammatory responses, may be involved in depression [241]. Fatty acid synthesis was among the top-ranked metabolic pathways. The levels of five fatty acids and L-acetylcarnitine were significantly decreased in the blood of MDD patients compared with controls. L-acetylcarnitine plays a pivotal role in the transport of fatty acids into the mitochondria for beta-oxidation, and L-acetylcarnitine supplementation was reported to have antidepressive effects [242]. The blood of patients with depression was also marked by higher levels of taurochenodesoxycholic acid, a bile acid formed from taurine in the liver [156]. This was 
confirmed in animal models of depression, which reported increased levels of taurochenodesoxycholic acid levels and decreased taurine levels in the liver [243,244], further emphasizing the link between primary bile acid synthesis and MDD. Bile acids are synthesized from cholesterol in the liver and further metabolized by the GM into secondary bile acids [245]. 25-Hydroxyvitamin D is the primary form of vitamin $\mathrm{D}$ in the human body. A deficiency in vitamin $\mathrm{D}$ has been associated with higher rates of suicide and a proinflammatory profile [246,247].

There are also several gut hormones, including NPY, GLP-1, cholecystokinin (CCK), and ghrelin, that are known to play important roles in mood disorders such as anxiety and depression. The neuropeptide Y family (NPY), including NPY, PYY, and pancreatic polypeptide (PP), are all involved in stress-related disorders, neuroprotection, neuroinflammation, and neurogenesis. Some of those peptides, namely NPY and PP, act by activating Y4 receptors, which are involved in the control of a wide range of behavioral processes [248].

GLP-1 is best known for its role in glucose-dependent insulin secretion. GLP-1 also responds to stress through the activation of the GLP-1 receptor [249]. Another regulator of the stress response is ghrelin, with adipogenic and orexigenic effects also identified as a regulator anxiety and depression [250].

Although the precise pathways mediating the GM communication with hormones have not yet been deciphered, growing pieces of evidence now suggest that microbiota is a key factor involved in the metabolism of hormones, and host hormones greatly influence the microbiota. One example included the reduction in leptin plasma levels following treatment with antibiotics [251]. The ghrelin levels are decreased when the GM composition is altered. When fasting, ghrelin level increased and prebiotic supplementation resulted in lower prospective food consumption and more feeling of fullness. Microbes may also regulate hormone secretion in an indirect way via their influence on the adrenal cortex and inflammatory response, all of which are closely related to the CNS and the GIT. For instance, certain bacterial components and metabolites promote the release of gut hormones from the EECs. Lipopolysaccharides (LPS) bind to Toll-like receptor 4 expressed in L-cells and triggers the secretion of GLP-1 in mice [252]. Gut hormones, on their part, signal ongoing processes to the microbes forcing them to act accordingly. A recent evolutionary-oriented study hypothesized that a variety of hormone metabolism related enzymes might have evolved from bacterial genes $[253,254]$.

Depression is connected with increased oxidative stress [255]. In this regard, the metabolites that somehow have an effect on OS in the body are good markers of depressive disorders. For instance, the study of Zheng et al. revealed increased levels of uric and azelaic acids in the urine [256]. Uric acid is formed in response to increased oxidative stress. Azelaic acid can have an antioxidant effect. The increased production of these compounds indirectly indicates a link between oxidative stress and depression. It is interesting to note that men and women with depression have different markers of OS. While women exhibited high levels of sorbitol and azelaic acid levels, in men, OS was associated with a decrease in cysteine and 1-methylinosine [257].

Glutathione (GSH) is the most abundant antioxidant in human tissue and an important indicator of antioxidant capacity and OS. According to a post-mortem study, the levels of reduced, oxidized, and total GSH are significantly lower in the PFC of MDD patients [106]. In the study of Eren et al. the induction of depressive-like behavior in Wistar rats resulted in a decrease in GSH and gluthatione peroxidase (GPx) levels and a rise in lipid peroxidation and nitric oxide in the cortex and medulla of the brain [258]. Comparative studies of GPx levels between people with depression and controls have yielded conflicting results. GPx levels were decreased [259,260], increased [261], or even unaltered [262] compared with healthy control groups. It is possible that the lack of uniform results between the studies is due to differences in the used methodology and sample selection bias. In bacteria, besides its role in maintaining the proper oxidation state of protein thiol, GSH serves a protective role against low $\mathrm{pH}$, chlorine compounds, oxidative and osmotic stress. The production of GSH among prokaryotes is limited to cyanobacteria and proteobacteria such as E. coli and Listeria monocytogenes, as well as gram-positive bacteria such as enterococci and streptococci [89-91]. GSH is from $\gamma$-glutamylcysteine 
by gluthatione synthetase. The favorable effects of probiotics on GSH levels (increasing synthesis) might be due to enhanced glutamate-cysteine ligase activity [250].

The immune system plays a crucial role in depression pathogenesis. A depressed patient presents immune dysregulation and chronic inflammation [4]. The cytokines, chemokines, endocrine messengers, and microbial products can infiltrate the blood and lymphatic systems or influence neural messages carried by the vagal and spinal afferent neurons, thereby affecting the regulation of the activity of the HPA and neuroinflammation.

Chronic inflammation and microglia activation are common features in depression $[263,264]$. Immunomodulation by bacteria is the important mechanism of CNS regulation. Many bacterial surface molecules, such as LPS, lipoproteins, and flagellins activate macrophages, neutrophils, and dendritic cells. Once activated, these cells produce proinflammatory interleukins IL-1a, IL-1b, TNFa, and IL-6 [265], which once carried over to the brain; interact with neuronal receptors and glial cells, in particular, turning on their "activation mode" and altering their properties [264]. The patients with depression have higher LPS levels and their immune system is far more active [266]. Some components of microbial cell walls facilitating adhesion to epithelial cells can trigger production and secretion of compounds capable of modulating neuronal signaling [267]. The GABA, acetylcholine, and norepinephrine, which can be produced by bacteria, exhibit immunomodulatory properties.

The identification of biomarkers associated with the GM may potentially expand diagnostic assessment of depressive disorders in clinical practice. The knowledge about the composition and metabolite potential of the GM may be applied as an additional diagnostic criterion as well as contribute to the assessment of disease severity. Together, they represent a future diagnostic tool for assessing the development of depressive disorders.

\section{The Therapeutic Potential of Functional Foods and Probiotics}

Today, diet remains one of the most effective measures that can be taken to restore the microbial balance in the gut [268] and alleviate the symptoms of depression. Given that diet has a profound effect on the composition and functional capacity of the GM, the salubrious potential of dietary intervention is no surprise. Foods rich in fiber and complex sugars act as a source of energy for beneficial bacteria, at the forefront of which are butyrate-producing bacteria. Fats and simple sugars, which are prominently consumed in abundance in the Western diet, should be avoided lest to nurture "bad" microorganisms known for their production of neurotropic metabolites [269]. Animal-derived protein and saturated fats are associated with Bacteroides abundance, while Prevotella are associated with carbohydrates and simple sugars [270]. A reduction in total carbohydrate in the diet reduces the butyrate-producing Roseburia/Eubacteriumrectale group [271]. High-sucrose feeding significantly decreases the abundance of Bacteroidetes in mice, while increasing the abundance of Proteobacteria, Firmicutes, and pathogenic Helicobacteraceae [272]. Vegetable-based diets can increase SCFAs, accompanied by elevated Prevotella and some fiber-degrading Firmicutes [273]. Increasing dietary fat alters the GM composition [219,236], possibly via the stimulation of bile and its modulation into secondary bile acid products [274].

The correlative studies of healthy adults showed that a lower incidence of depression occurs when using "healthy" dietary patterns with an abundance of vegetables, fruits, as well as moderate amounts of dairy, eggs, and fish, and unsaturated fats [275-277]. A 10-y longitudinal study in France showed an association between depression incidence and poor diet, but found that there was most likely reverse causality, with depression increasing the risk of poor eating behaviors [278].

A diet poor in PUFAs is more than likely to contribute to the development of depression [234]. Moreover, patients with depression display lower serum levels of omega-3 and of omega-6 PUFAs, both used as building blocks by nerve cells [279]. Insufficient intake of fish, meat and nuts offers often a valid explanation for PUFA deficiency. Therefore, dietary supplementation with foods rich with omega-3 and omega-6 PUFAs can efficiently ameliorate depression symptoms and improve cognitive function. 
By the same token, replacing inflammatory foods, such as sugar, gluten, artificial trans fats, chemical additives, taste enhancers, and preservatives with anti-inflammatory foods, such as berries, avocado, broccoli, olive oil, cocoa, and green tea, can be a huge step towards mitigating the heightened inflammatory response of the immune system [280]. Fungal glycans, phytosterols and flavonoids also have immunomodulating properties. There is enough evidence showing that diet is a powerful modulator of the immune response and a determinant of social behavior in patients with depression. For example, luteolin, a natural flavonoid, inhibits the release of proinflammatory IL-6 from mast cells [281].

Functional foods hold great promise as enhancers of aberrant behavior and cognition in people with depression. A functional diet consumed on a daily basis, whether consisting of natural or synthetic nutrients, can primarily normalize the intestinal microecology and secondarily recover vital physiological functions and biochemical reactions. Functional foods fulfill both a protective and a preventive function. There is a wide variety of functional foods with potential curative effects with regard to depression. These are foods rich in fiber (prebiotics), probiotics (bifidobacteria and lactobacilli), antioxidants and vitamins (A, E, C, and group B), mineral elements (calcium, microelements (iron, zinc, fluorine, selenium, etc.), PUFAs, plant sterols, conjugated linoleic acid isomers, structured lipids, sphingolipids, polysaccharides and secondary plant-derived compounds (flavonoids, polyphenols, carotenes, licopene), taurine, co-enzyme Q10, and carnitine.

Strains of lactobacilli and bifidobacteria can be selected based on their genetic and genomic differences favoring those that are more likely to impart health benefits to the nervous system in humans [282]. Bifidobacteria, in particular, are known for their ability to counter inflammation [283]. Such elaborately chosen strains can be taken as live food supplements. In the last decades, the discovery of unique strains of lactobacillus and bifiobacteria capable of improving symptoms of psychiatric diseases and even alter behavior led to a paradigm shift in the field of psychiatry [284,285]. These bacteria were named 'psychobiotics' and were defined as live bacteria that can benefit mental health. Psychobiotics were proposed as a viable alternative to standard pharmacological treatment, which is often discredited for its infamous adverse effects and controversial effectiveness. Psychobiotics secrete a wide range of signaling molecules that operate via distinct pathways to exert their effects, be it antidepressive, immunomodulatory, or modulation of neurotransmission. Different strains of psychobiotics were tested within both preclinical and clinical setups for their potential to treat of depression. While some studies failed to reproduce the animal results in humans, others yielded robust antidepressant effects coupled with a shift in the Bacteroidetes:Firmicutes ratio and increased the abundance of bifidobacteria [286]. Some psychobiotics were recommended as adjuvants for anti-depressant therapy $[287,288]$. Since diet largely determines the composition of the GM, it is an important variable in the connection between the gut and nervous system diseases.

Because diet has a greater impact on the composition and function of the GM, it is likely that changes in diet (whole diet and individual components of diet) may affect depression. Currently, research in this area is limited and mainly conducted on rodents. Dietary models for positive effects on mental health will focus on maintaining the growth of beneficial commensal microbiota, reducing the growth of pathogenic microbiota, and influencing intestinal barrier permeability and inflammation. However, it is important to remember that diet will affect the collective function and characteristics of the GM that interact with the host. Similar functions can be carried out by different microbiota structures and the same functional outcome could occur with different changes in microbiota. Therefore, the type and strength of the effect of diet on the GM will be determined by the existing composition and function of the microbiota. Research needs to include examination of the GM function using metabolomics and/or metagenomics techniques.

A healthy diet during the depression therapy, along with the application of probiotics and psychobiotics, may potentially improve the course of the disease and contribute to the progress of treatment. 


\section{The Utility of Reference Gene Catalogs for Understanding the GM}

The GM developed in the process of evolution the necessary machinery in the form of specialized enzymes that enabled it to produce various active compounds. Overall, the functional potential of the GM depends on the diversity and relative abundance of bacterial genes. As the cost and accuracy of high-throughput sequencing evolved to meet the needs of scientists, the analysis of collective bacterial genomes known as metagenomes, have become an irreplaceable and reliable tool in GM research [289]. Whole metagenome sequencing allows us to search for specific bacterial genes and rebuild the functional capacity of the sampled microbiota. However, such analyses can yield meaningful results only when the right targeted genes are built into the reference gene catalog of the search tool. Table 5 provides an example of a gene catalog comprising the key bacterial enzymes relevant to depression.

There are many ways to functionally annotate a metagenome. The easiest way is to use the RefSeq database, which is one of the richest databases in homologous sequences [290]. While such an approach may generate high-resolution results, it still produces a large number of false-positive results due to a poor representation of certain bacterial metabolic pathways. For instance, to produce dopamine, gut bacteria use tyrosine decarboxylase rather than dopa decarboxylase [291]. The second way is to use databases of metabolic pathways such as KEGG [292] or MetaCyc [293]. This approach is more reliable since, as in the case of KEGG and MetaCyc, such databases are constantly updated. Although such a detailed analysis may be applicable for characterizing the functional potential of metagenomes, the results remain of little diagnostic value. The third way consists of selecting the genes of interest and by creating a customized gene catalog. Gene catalogs consist of consensus sequences of genes that are obtained by consulting the main research databases such as Pubmed, databases such as SwissProt, InterPro, KEGG, MetaCyc, etc. The genes are selected in conformance with the envisaged purpose of the gene catalog, such as to determine the neuromodulatory potential of the metagenome. Reference gene catalogs not only allow to detect the targeted genes but also evaluate the relative abundance of these genes in a metagenome sample. Several variants of reference catalogs of genes involved in the synthesis of neuroactive compounds currently exist. The first catalog was developed by Kovtun et al. [294]. This gene catalog was designed to characterize the core metagenomic neuromodulatory potential of the human's GM in the norm. The second variant was extended to include genes involved in the production of compounds relevant to autism spectrum disorders [24]. The gene catalog was proven effective for revealing significant changes in the metagenomic signature of the GM of children with ASD from the Moscow region [24]. Presently, more genes are being added to the gene catalog, thereby redirecting its purpose to various neuropsychiatric disorders. The complete composition of the catalog at the moment of writing of this review is provided in Table 5. Another gene catalog aimed at characterizing the neuroactive potential of the human GM was created by Valles-Colomer et al. [53]. The gene catalog was successfully utilized by the authors to search for associations between the GM and depression and schizophrenia $[53,295]$. 
Table 5. Gene catalog of the key bacterial enzymes relevant to depression.

\begin{tabular}{|c|c|c|c|}
\hline Functions & Enzymes & Functions & Enzymes \\
\hline $\begin{array}{l}\text { Synthesis of serotonin, dopamine and } \\
\text { norepinephrine }\end{array}$ & Dopa decarboxylase & Synthesis of butyrate & Butyrate kinase \\
\hline Synthesis of GABA & Glutamate decarboxylase & Formation of butyric acid & Butyryl-CoA dehydrogenase \\
\hline Transportation of GABA & Gamma-aminobutyrate antiporter & \multirow{3}{*}{ Formation of propionic acid } & Lactoyl-CoA dehydratase \\
\hline \multirow{3}{*}{ Degradation of GABA } & 4-aminobutyrate aminotransferase (gabT) & & Propionaldehyde dehydrogenase \\
\hline & 4-aminobutyrate aminotransferase (puuE) & & Methylmalonyl-CoA decarboxylase \\
\hline & Glycine amidinotransferase & Conjugation of linoleic acid & Linoleic acid isomerase \\
\hline Synthesis of histamine & Histidine decarboxylase & Synthesis of spermidine & Spermidine synthase \\
\hline $\begin{array}{c}\text { Degradation of serotonin for melatonin } \\
\text { synthesis }\end{array}$ & Serotonin $\mathrm{N}$-acetyltransferase & Synthesis of tyramine and dopamine & Tyrosine decarboxylase \\
\hline Synthesis of melatonin & Acetylserotonin O-methyltransferase & \multirow{3}{*}{$\begin{array}{l}\text { Synthesis of isovaleric acid } \\
\text { (KADH pathway) }\end{array}$} & 2-oxoisovalerate dehydrogenase alpha \\
\hline Formation of nitric oxide & Nitric oxide synthase & & 2-oxoisovalerate dehydrogenase beta \\
\hline \multirow{3}{*}{ Degradation of nitric oxide } & Nitric oxide dioxygenase & & Dihydrolipoyl dehydrogenase \\
\hline & Nitric oxide reductase norB & \multirow{2}{*}{$\begin{array}{l}\text { Synthesis of isovaleric acid } \\
\text { (KADC pathway) }\end{array}$} & Aldehyde dehydrogenase \\
\hline & Nitric oxide reductase norC & & Pyruvate decarboxylase \\
\hline Synthesis of catecholamines & Aromatic amino acid hydroxylases & \multirow[b]{2}{*}{ Synthesis of inositol } & Myo-inositol-1(or 4)-monophosphatase \\
\hline $\begin{array}{c}\text { Degradation of serotonin, dopamine and } \\
\text { norepinephrine }\end{array}$ & Monoamine oxidase & & Myo-inositol-1-phosphate synthase \\
\hline Formation of acetic acid & Phosphotransacetylase & Degradation of inositol & Myo-inositol 2-dehydrogenase \\
\hline Degradation of $\gamma$-hydroxybutyric acid & 4-hydroxybutyrate dehydrogenase & \multirow{3}{*}{ Degradation of glutathione } & Glutathione S-transferase \\
\hline \multirow{2}{*}{ Synthesis of glutamate II } & Glutamate synthase gltB & & Glutathione reductase \\
\hline & Glutamate synthase gltD & & Gamma-glutamyltranspeptidase \\
\hline \multirow{3}{*}{ Degradation of glutamate II } & Glutamate mutase glmS & Degradation of histidine & Histidine ammonia-lyase \\
\hline & Glutamate mutase glmE & Synthesis of 4-etylphenol & Vinylphenol reductase \\
\hline & Methylaspartate ammonia-lyase & Synthesis of indole from tryptophane & Tryptophanase \\
\hline
\end{tabular}


Table 5. Cont.

\begin{tabular}{|c|c|c|c|}
\hline Functions & Enzymes & Functions & Enzymes \\
\hline Synthesis of p-cresol & 4-hydroxyphenylacetate decarboxylase & Synthesis of prephenate & Chorismate mutase \\
\hline \multirow{3}{*}{ Degradation of $\mathrm{p}$-cresol } & 4-cresol dehydrogenase & $\begin{array}{c}\text { Synthesis of } \\
\text { 4-hydroxyphenylpyruvate }\end{array}$ & Prephenate dehydrogenase \\
\hline & Protocatechuate 3,4-dioxygenase pcaG & Transportation of tyrosine & Tyrosine-specific transport protein \\
\hline & Protocatechuate 3,4-dioxygenase pcaH & Synthesis of tyrosine & Tyrosine aminotransferase \\
\hline Synthesis of creatinine & Creatinine amidohydrolase & Synthesis of phenylalanine & Phenylalanine aminotransferase \\
\hline Formation of D-lactic acid & D-lactate dehydrogenase & Transportation of phenylalanine & Phenylalanine-specific permease \\
\hline \multirow{2}{*}{ Synthesis of glutathione } & Glutathione synthetase, gshB & \multirow{2}{*}{ Synthesis of tryptophan } & Tryptophan synthetase, subunit alpha \\
\hline & Glutathione synthetase, gshAB & & Tryptophan synthetase, subunit beta \\
\hline \multirow{2}{*}{ Transportation of tryptophan } & Tryptophan-specific transport protein & & \\
\hline & Tryptophan permease & & \\
\hline \multirow{5}{*}{ Antioxidants } & Superoxide dismutase, [Mn] & & \\
\hline & Superoxide dismutase, $[\mathrm{Fe}]$ & & \\
\hline & Superoxide dismutase, [Cu-Zn] & & \\
\hline & Catalase & & \\
\hline & Glutathione peroxidase & & \\
\hline
\end{tabular}




\section{Conclusions}

Depression is multifactorial disease and today, different theories and hypotheses aspiring to explain the etiology of depressive disturbance. They range from dysfunction of neurotransmitter systems to neuroinflammation, metabolic abnormality, deficit of neurotrophic factors, and others. Although a large number of depression biomarkers have been identified, an effective panel of markers is still lacking in clinical practice. Despite the knowledge about the participation of the GM in the bidirectional communication between the gut and the brain and its role in the development of various neuropsychiatric disorders the study of the influence of the GM on depressive disorders is currently in its infancy. The data presented in this review promotes the understanding of the role of the GM in the pathogenesis of depression.

The purpose of this review was to discuss biomarkers of depression correlating with the GM, which included the neurotransmitters serotonin, norepinephrine and/or dopamine, GABA and glutamate; SCFAs; amino acids and other metabolites with neuro- and immunomodulation. The relationship between these biomarkers and depression has been shown in animal models and humans. The observed changes in the composition of the GM of patients with depression provide to the development of new strategies to depression therapy through the impact on the GM. In this review, we described the therapeutic potential of the functional foods and psychobiotics and their antidepressant effects. These strategies provide an effective alternative for the treatment of mental disorders.

The use of the GM biomarkers, reflecting the neuromodulatory, immunomodulatory and antioxidant statuses of the host organism, in the analysis of metagenomic data from patients with neuropsychiatric diseases, is gaining currency. Creating gene catalogs containing functional genes will allow purposeful analyze of the metagenomic data. Defining the metagenomic signature in the norm is crucial for singling out the genes with a diagnostic potential in the context of depression. Bacterial genes encoding enzymes involved in the metabolism of biomarkers described in this review most likely determine the neuro- and immunomodulatory potential of the microbiomes that contribute to depressive manifestations, and can be used to identify the metabolic signature of the GM of patients with depression.

Further progress in our practical understanding of the role of the GM in depression will depend greatly on correct planning of future metagenomic studies. These studies need to be uniformly carried out by criteria of the formation of patient cohorts, choosing definitive biochemical and genetic biomarkers, and using new bioinformatics approaches for deeper analysis. The new knowledge about the GM will form the basis for the development of fundamentally new methods of treatment and diagnosis of depression in clinical practice.

Author Contributions: Conceptualization, O.V.A., and V.N.D.; Writing-Original Draft Preparation, O.V.A. and Y.A.Z.; Writing一Review \& Editing, O.V.A., Y.A.Z., R.A.Y., A.S.K., V.M.U., A.Y.M.; Visualization, Y.A.Z., G.P.K., V.M.U.; Supervision, V.N.D., G.P.K., V.P.C.; Project Administration, O.V.A.; Funding Acquisition, O.V.A., V.N.D. All authors have read and agreed to the published version of the manuscript.

Funding: The study was granted by the Russian Science Foundation, project no. 20-14-00132.

Conflicts of Interest: The authors declare no conflict of interest.

\section{References}

1. Friedrich, M.J. Depression is the leading cause of disability around the world. JAMA 2017, $317,1517$. [CrossRef] [PubMed]

2. Alduhishy, M. The overprescription of antidepressants and its impact on the elderly in Australia. Trends Psychiatry Psychother. 2018, 40, 241-243. [CrossRef] [PubMed]

3. Olfson, M.; Marcus, S.C. National patterns in antidepressant medication treatment. Arch. Gen. Psychiatry 2009, 66, 848-856. [CrossRef] [PubMed] 
4. Otte, C.; Gold, S.M.; Penninx, B.W.; Pariante, C.M.; Etkin, A.; Fava, M.; Mohr, D.C.; Schatzberg, A.F. Major depressive disorder. Nat. Rev. Dis. Primers 2016, 2, 1-20. [CrossRef] [PubMed]

5. Stefano, G.; Pilonis, N.; Ptacek, R.; Raboch, J.; Vnukova, M.; Kream, R. Gut, microbiome, and brain regulatory axis: Relevance to neurodegenerative and psychiatric disorders. Cell. Mol. Neurobiol. 2018, 38, 1197-1206. [CrossRef] [PubMed]

6. Makris, A.P.; Karianaki, M.; Tsamis, K.I. The role of the gut-brain axis in depression: Endocrine, neural, and immune pathways. Hormones 2020, 1-12. [CrossRef] [PubMed]

7. Karl, J.P.; Hatch, A.M.; Arcidiacono, S.M.; Pearce, S.C.; Pantoja-Feliciano, I.G.; Doherty, L.A.; Soares, J.W. Effects of psychological, environmental and physical stressors on the gut microbiota. Front. Microbiol. 2018, 9, 2013. [CrossRef]

8. Caspani, G.; Kennedy, S.; Foster, J.A.; Swann, J. Gut microbial metabolites in depression: Understanding the biochemical mechanisms. Microb. Cell 2019, 6, 454. [CrossRef]

9. Therese, L.; Khan, F.; Eskander, N. Gut Microbiome and Depression: How Microbes Affect the Way We Think. Cureus 2020, 12, 8.

10. Capuco, A.; Urits, I.; Hasoon, J.; Chun, R.; Gerald, B.; Wang, J.K.; Kassem, H.; Ngo, A.L.; Abd-Elsayed, A.; Simopoulos, T. Current perspectives on gut microbiome dysbiosis and depression. Adv. Ther. 2020, 37, 1328-1346. [CrossRef]

11. Bear, T.L.; Dalziel, J.E.; Coad, J.; Roy, N.C.; Butts, C.A.; Gopal, P.K. The Role of the Gut Microbiota in Dietary Interventions for Depression and Anxiety. Adv. Nutr. 2020, 11, 890-907. [CrossRef] [PubMed]

12. Bastiaanssen, T.F.; Cussotto, S.; Claesson, M.J.; Clarke, G.; Dinan, T.G.; Cryan, J.F. Gutted! Unraveling the role of the microbiome in major depressive disorder. Harv. Rev. Psychiatry 2020, 28, 26-39. [CrossRef] [PubMed]

13. Gheshlagh, R.G.; Parizad, N.; Sayehmiri, K. The relationship between depression and metabolic syndrome: Systematic review and meta-analysis study. Iran. Red Crescent Med. J. 2016, 18, e26523. [CrossRef] [PubMed]

14. Marchesi, J.R. Prokaryotic and eukaryotic diversity of the human gut. In Advances in Applied Microbiology; Elsevier: Amsterdam, The Netherlands, 2010; Volume 72, pp. 43-62.

15. Qin, J.; Li, R.; Raes, J.; Arumugam, M.; Burgdorf, K.S.; Manichanh, C.; Nielsen, T.; Pons, N.; Levenez, F.; Yamada, T. A human gut microbial gene catalogue established by metagenomic sequencing. Nature 2010, 464, 59-65. [CrossRef] [PubMed]

16. Borre, Y.E.; Moloney, R.D.; Clarke, G.; Dinan, T.G.; Cryan, J.F. The impact of microbiota on brain and behavior: Mechanisms \& therapeutic potential. In Microbial Endocrinology: The Microbiota-Gut-Brain Axis in Health and Disease; Springer: Berlin/Heidelberg, Germany, 2014; pp. 373-403.

17. Wang, Y.; Kasper, L.H. The role of microbiome in central nervous system disorders. BrainBehav. Immun. 2014, 38, 1-12. [CrossRef]

18. Fetissov, S.O.; Averina, O.V.; Danilenko, V.N. Neuropeptides in the microbiota-brain axis and feeding behavior in autism spectrum disorder. Nutrition 2019, 61, 43-48. [CrossRef]

19. Brown, J.M.; Hazen, S.L. The gut microbial endocrine organ: Bacterially derived signals driving cardiometabolic diseases. Annu. Rev. Med. 2015, 66, 343-359. [CrossRef]

20. Luczynski, P.; Whelan, S.O.; O’Sullivan, C.; Clarke, G.; Shanahan, F.; Dinan, T.G.; Cryan, J.F. Adult microbiota-deficient mice have distinct dendritic morphological changes: Differential effects in the amygdala and hippocampus. Eur. J. Neurosci. 2016, 44, 2654-2666. [CrossRef]

21. Bravo, J.A.; Julio-Pieper, M.; Forsythe, P.; Kunze, W.; Dinan, T.G.; Bienenstock, J.; Cryan, J.F. Communication between gastrointestinal bacteria and the nervous system. Curr. Opin. Pharmacol. 2012, 12, 667-672. [CrossRef]

22. Stilling, R.; Dinan, T.; Cryan, J. Microbes do have a significant impact on epigenetic regulation in the host's gut epithelium and immune system, microbial genes, brain and behaviour-epigenetic regulation of the gut-brain axis. Genes Brain Behav. 2014, 13, 69-86. [CrossRef]

23. Sampson, T.R.; Mazmanian, S.K. Control of brain development, function, and behavior by the microbiome. Cell Host Microbe 2015, 17, 565-576. [CrossRef] [PubMed]

24. Averina, O.V.; Kovtun, A.S.; Polyakova, S.I.; Savilova, A.M.; Rebrikov, D.V.; Danilenko, V.N. The bacterial neurometabolic signature of the gut microbiota of young children with autism spectrum disorders. J. Med. Microbiol. 2020, 69, 558-571. [CrossRef] [PubMed]

25. Forgie, A.J.; Drall, K.M.; Bourque, S.L.; Field, C.J.; Kozyrskyj, A.L.; Willing, B.P. The impact of maternal and early life malnutrition on health: A diet-microbe perspective. BMC Med. 2020, 18, 1-15. [CrossRef] 
26. Kovtun, A.S.; Averina, O.V.; Alekseeva, M.G.; Danilenko, V.N. Antibiotic resistance genes in the gut microbiota of children with autistic spectrum disorder as possible predictors of the disease. Microb. Drug Resist. 2020, 26, 1307-1320. [CrossRef] [PubMed]

27. Wang, X.; Wang, B.-R.; Zhang, X.-J.; Xu, Z.; Ding, Y.-Q.; Ju, G. Evidences for vagus nerve in maintenance of immune balance and transmission of immune information from gut to brain in STM-infected rats. World J. Gastroenterol. 2002, 8, 540. [CrossRef] [PubMed]

28. Wang, H.; Yu, M.; Ochani, M.; Amella, C.A.; Tanovic, M.; Susarla, S.; Li, J.H.; Wang, H.; Yang, H.; Ulloa, L. Nicotinic acetylcholine receptor $\alpha 7$ subunit is an essential regulator of inflammation. Nature 2003, 421, 384-388. [CrossRef] [PubMed]

29. De Lartigue, G.; de La Serre, C.B.; Raybould, H.E. Vagal afferent neurons in high fat diet-induced obesity; intestinal microflora, gut inflammation and cholecystokinin. Physiol. Behav. 2011, 105, 100-105. [CrossRef]

30. Sternberg, E.M. Neural regulation of innate immunity: A coordinated nonspecific host response to pathogens. Nat. Rev. Immunol. 2006, 6, 318-328. [CrossRef]

31. Dantzer, R.; O'Connor, J.C.; Freund, G.G.; Johnson, R.W.; Kelley, K.W. From inflammation to sickness and depression: When the immune system subjugates the brain. Nat. Rev. Neurosci. 2008, 9, 46-56. [CrossRef]

32. MacFabe, D.F.; Cain, N.E.; Boon, F.; Ossenkopp, K.-P.; Cain, D.P. Effects of the enteric bacterial metabolic product propionic acid on object-directed behavior, social behavior, cognition, and neuroinflammation in adolescent rats: Relevance to autism spectrum disorder. Behav. Brain Res. 2011, 217, 47-54. [CrossRef]

33. Thomas, C.M.; Hong, T.; Van Pijkeren, J.P.; Hemarajata, P.; Trinh, D.V.; Hu, W.; Britton, R.A.; Kalkum, M.; Versalovic, J. Histamine derived from probiotic Lactobacillus reuteri suppresses TNF via modulation of PKA and ERK signaling. PLoS ONE 2012, 7, e31951. [CrossRef] [PubMed]

34. Burke, H.M.; Davis, M.C.; Otte, C.; Mohr, D.C. Depression and cortisol responses to psychological stress: A meta-analysis. Psychoneuroendocrinology 2005, 30, 846-856. [CrossRef] [PubMed]

35. Köhler, C.; Freitas, T.; Maes, M.D.; De Andrade, N.; Liu, C.; Fernandes, B.; Stubbs, B.; Solmi, M.; Veronese, N.; Herrmann, N. Peripheral cytokine and chemokine alterations in depression: A meta-analysis of 82 studies. Acta Psychiatr. Scand. 2017, 135, 373-387. [CrossRef] [PubMed]

36. Chambers, A.S.; Allen, J.J. Vagal tone as an indicator of treatment response in major depression. Psychophysiology 2002, 39, 861-864. [CrossRef] [PubMed]

37. Krishnan, V.; Nestler, E.J. The molecular neurobiology of depression. Nature 2008, 455, 894-902. [CrossRef] [PubMed]

38. Ghosal, S.; Hare, B.D.; Duman, R.S. Prefrontal cortex GABAergic deficits and circuit dysfunction in the pathophysiology and treatment of chronic stress and depression. Curr. Opin. Behav. Sci. 2017, 14, 1-8. [CrossRef]

39. Barajon, I.; Serrao, G.; Arnaboldi, F.; Opizzi, E.; Ripamonti, G.; Balsari, A.; Rumio, C. Toll-like receptors 3, 4, and 7 are expressed in the enteric nervous system and dorsal root ganglia. J. Histochem. Cytochem. 2009, 57, 1013-1023. [CrossRef]

40. Brun, P.; Giron, M.C.; Qesari, M.; Porzionato, A.; Caputi, V.; Zoppellaro, C.; Banzato, S.; Grillo, A.R.; Spagnol, L.; De Caro, R. Toll-like receptor 2 regulates intestinal inflammation by controlling integrity of the enteric nervous system. Gastroenterology 2013, 145, 1323-1333. [CrossRef]

41. Grenham, S.; Clarke, G.; Cryan, J.F.; Dinan, T.G. Brain-gut-microbe communication in health and disease. Front. Physiol. 2011, 2, 94. [CrossRef]

42. Khanna, S.; Tosh, P.K. A clinician's primer on the role of the microbiome in human health and disease. In Mayo Clinic Proceedings; Elsevier: Amsterdam, The Netherlands, 2014; pp. 107-114.

43. Yano, J.M.; Yu, K.; Donaldson, G.P.; Shastri, G.G.; Ann, P.; Ma, L.; Nagler, C.R.; Ismagilov, R.F.; Mazmanian, S.K.; Hsiao, E.Y. Indigenous bacteria from the gut microbiota regulate host serotonin biosynthesis. Cell 2015, 161, 264-276. [CrossRef]

44. Lyte, M.; Cryan, J.F. Microbial Endocrinology: The Microbiota-Gut-Brain Axis in Health and Disease; Springer: Berlin/Heidelberg, Germany, 2014; Volume 817.

45. Averina, O.V.; Danilenko, V.N. Human intestinal microbiota: Role in development and functioning of the nervous system. Microbiology 2017, 86, 1-18. [CrossRef]

46. Barandouzi, Z.A.; Starkweather, A.R.; Henderson, W.A.; Gyamfi, A.; Cong, X.S. Altered Composition of Gut Microbiota in Depression: A Systematic Review. Front. Psychiatry. 2020, 11, 541. [CrossRef] [PubMed] 
47. Sanada, K.; Nakajima, S.; Kurokawa, S.; Barceló-Soler, A.; Ikuse, D.; Hirata, A.; Yoshizawa, A.; Tomizawa, Y.; Salas-Valero, M.; Noda, Y. Gut microbiota and major depressive disorder: A systematic review and meta-analysis. J. Affect. Disord. 2020, 266, 1-13. [CrossRef] [PubMed]

48. Jiang, H.; Ling, Z.; Zhang, Y.; Mao, H.; Ma, Z.; Yin, Y.; Wang, W.; Tang, W.; Tan, Z.; Shi, J. Altered fecal microbiota composition in patients with major depressive disorder. Brain Behav. Immun. 2015, 48, 186-194. [CrossRef]

49. Kelly, J.R.; Borre, Y.; O’Brien, C.; Patterson, E.; El Aidy, S.; Deane, J.; Kennedy, P.J.; Beers, S.; Scott, K.; Moloney, G. Transferring the blues: Depression-associated gut microbiota induces neurobehavioural changes in the rat. J. Psychiatr. Res. 2016, 82, 109-118. [CrossRef]

50. Naseribafrouei, A.; Hestad, K.; Avershina, E.; Sekelja, M.; Linløkken, A.; Wilson, R.; Rudi, K. Correlation between the human fecal microbiota and depression. Neurogastroenterol. Motil. 2014, 26, 1155-1162. [CrossRef]

51. Liu, Y.; Zhang, L.; Wang, X.; Wang, Z.; Zhang, J.; Jiang, R.; Wang, X.; Wang, K.; Liu, Z.; Xia, Z. Similar fecal microbiota signatures in patients with diarrhea-predominant irritable bowel syndrome and patients with depression. Clin. Gastroenterol. Hepatol. 2016, 14, 1602.e5-1611.e5. [CrossRef]

52. Aizawa, E.; Tsuji, H.; Asahara, T.; Takahashi, T.; Teraishi, T.; Yoshida, S.; Ota, M.; Koga, N.; Hattori, K.; Kunugi, H. Possible association of Bifidobacterium and Lactobacillus in the gut microbiota of patients with major depressive disorder. J. Affect. Disord. 2016, 202, 254-257. [CrossRef]

53. Valles-Colomer, M.; Falony, G.; Darzi, Y.; Tigchelaar, E.F.; Wang, J.; Tito, R.Y.; Schiweck, C.; Kurilshikov, A.; Joossens, M.; Wijmenga, C. The neuroactive potential of the human gut microbiota in quality of life and depression. Nat. Microbiol. 2019, 4, 623-632. [CrossRef]

54. Szczesniak, O.; Hestad, K.A.; Hanssen, J.F.; Rudi, K. Isovaleric acid in stool correlates with human depression. Nutr. Neurosci. 2016, 19, 279-283. [CrossRef]

55. Huang, T.-T.; Lai, J.-B.; Du, Y.-L.; Xu, Y.; Ruan, L.-M.; Hu, S.-H. Current understanding of gut microbiota in mood disorders: An update of human studies. Front. Genet. 2019, 10, 98. [CrossRef] [PubMed]

56. Huang, Y.; Shi, X.; Li, Z.; Shen, Y.; Shi, X.; Wang, L.; Li, G.; Yuan, Y.; Wang, J.; Zhang, Y. Possible association of Firmicutes in the gut microbiota of patients with major depressive disorder. Neuropsychiatr. Dis. Treat. 2018, 14, 3329. [CrossRef] [PubMed]

57. Cheung, S.G.; Goldenthal, A.R.; Uhlemann, A.-C.; Mann, J.J.; Miller, J.M.; Sublette, M.E. Systematic review of gut microbiota and major depression. Front. Psychiatry 2019, 10, 34. [CrossRef] [PubMed]

58. Bonder, M.J.; Kurilshikov, A.; Tigchelaar, E.F.; Mujagic, Z.; Imhann, F.; Vila, A.V.; Deelen, P.; Vatanen, T.; Schirmer, M.; Smeekens, S.P. The effect of host genetics on the gut microbiome. Nat. Genet. 2016, 48, 1407-1412. [CrossRef]

59. David, L.A.; Maurice, C.F.; Carmody, R.N.; Gootenberg, D.B.; Button, J.E.; Wolfe, B.E.; Ling, A.V.; Devlin, A.S.; Varma, Y.; Fischbach, M.A. Diet rapidly and reproducibly alters the human gut microbiome. Nature 2014, 505, 559-563. [CrossRef]

60. O'Toole, P.W.; Jeffery, I.B. Gut microbiota and aging. Science 2015, 350, 1214-1215. [CrossRef]

61. He, Y.; Wu, W.; Zheng, H.-M.; Li, P.; McDonald, D.; Sheng, H.-F.; Chen, M.-X.; Chen, Z.-H.; Ji, G.-Y.; Mujagond, P. Regional variation limits applications of healthy gut microbiome reference ranges and disease models. Nat. Med. 2018, 24, 1532-1535. [CrossRef]

62. Vernocchi, P.; Del Chierico, F.; Putignani, L. Gut microbiota profiling: Metabolomics based approach to unravel compounds affecting human health. Front. Microbiol. 2016, 7, 1144. [CrossRef]

63. Zheng, P.; Chen, J.-J.; Huang, T.; Wang, M.-J.; Wang, Y.; Dong, M.-X.; Huang, Y.-J.; Zhou, L.-K.; Xie, P. A novel urinary metabolite signature for diagnosing major depressive disorder. J. Proteome Res. 2013, 12, 5904-5911. [CrossRef]

64. Shishov, V.; Kirovskaya, T.; Kudrin, V.; Oleskin, A. Amine neuromediators, their precursors, and oxidation products in the culture of Escherichia coli K-12. Appl. Biochem. Microbiol. 2009, 45, 494-497. [CrossRef]

65. Özoğul, F. Production of biogenic amines by Morganella morganii, Klebsiella pneumoniae and Hafnia alvei using a rapid HPLC method. Eur. Food Res. Technol. 2004, 219, 465-469. [CrossRef]

66. Özoğul, F.; Kuley, E.; ÖZOĞUL, Y.; ÖZOĞUL, İ. The function of lactic acid bacteria on biogenic amines production by food-borne pathogens in arginine decarboxylase broth. Food Sci. Technol. Res. 2012, 18, 795-804. [CrossRef] 
67. O'Mahony, S.M.; Clarke, G.; Borre, Y.; Dinan, T.; Cryan, J. Serotonin, tryptophan metabolism and the brain-gut-microbiome axis. Behav. Brain Res. 2015, 277, 32-48. [CrossRef] [PubMed]

68. Dinan, T.G.; Stilling, R.M.; Stanton, C.; Cryan, J.F. Collective unconscious: How gut microbes shape human behavior. J. Psychiatr. Res. 2015, 63, 1-9. [CrossRef]

69. Tsavkelova, E.; Botvinko, I.; Kudrin, V.; Oleskin, A. Detection of neurotransmitter amines in microorganisms with the use of high-performance liquid chromatography. Dokl. Biochem. Proc. Acad. Sci. USSR Biochem. Sect. 2000, 372, 115.

70. Yunes, R.; Poluektova, E.; Dyachkova, M.; Klimina, K.; Kovtun, A.; Averina, O.; Orlova, V.; Danilenko, V. GABA production and structure of gadB/gadC genes in Lactobacillus and Bifidobacterium strains from human microbiota. Anaerobe 2016, 42, 197-204. [CrossRef]

71. Strandwitz, P.; Kim, K.H.; Terekhova, D.; Liu, J.K.; Sharma, A.; Levering, J.; McDonald, D.; Dietrich, D.; Ramadhar, T.R.; Lekbua, A. GABA-modulating bacteria of the human gut microbiota. Nat. Microbiol. 2019, 4, 396-403. [CrossRef]

72. Stromeck, A.; Hu, Y.; Chen, L.; Gaänzle, M.G. Proteolysis and bioconversion of cereal proteins to glutamate and $\gamma$-aminobutyrate (GABA) in rye malt sourdoughs. J. Agric. Food Chem. 2011, 59, 1392-1399. [CrossRef]

73. Lin, Q. Submerged fermentation of Lactobacillus rhamnosus YS9 for $\gamma$-aminobutyric acid (GABA) production. Braz. J. Microbiol. 2013, 44, 183-187. [CrossRef]

74. Liu, R.; Hong, J.; Xu, X.; Feng, Q.; Zhang, D.; Gu, Y.; Shi, J.; Zhao, S.; Liu, W.; Wang, X. Gut microbiome and serum metabolome alterations in obesity and after weight-loss intervention. Nat. Med. 2017, $23,859$. [CrossRef]

75. Ikeda, M. Towards bacterial strains overproducing L-tryptophan and other aromatics by metabolic engineering. Appl. Microbiol. Biotechnol. 2006, 69, 615. [CrossRef] [PubMed]

76. Han, Q.; Fang, J.L.I.J. Kynurenine aminotransferase and glutamine transaminase K of Escherichia coli: Identity with aspartate aminotransferase. Biochem. J. 2001, 360, 617-623. [CrossRef] [PubMed]

77. Sofia, M.A.; Ciorba, M.A.; Meckel, K.; Lim, C.K.; Guillemin, G.J.; Weber, C.R.; Bissonnette, M.; Pekow, J.R. Tryptophan metabolism through the kynurenine pathway is associated with endoscopic inflammation in ulcerative colitis. Inflamm. Bowel Dis. 2018, 24, 1471-1480. [CrossRef] [PubMed]

78. Katoh, A.; Uenohara, K.; Akita, M.; Hashimoto, T. Early steps in the biosynthesis of NAD in Arabidopsis start with aspartate and occur in the plastid. Plant Physiol. 2006, 141, 851-857. [CrossRef]

79. Yanofsky, C.; Horn, V.; Gollnick, P. Physiological studies of tryptophan transport and tryptophanase operon induction in Escherichia coli. J. Bacteriol. 1991, 173, 6009-6017. [CrossRef]

80. Lee, J.-H.; Lee, J. Indole as an intercellular signal in microbial communities. FEMS Microbiol. Rev. 2010, 34, 426-444. [CrossRef]

81. Louis, P.; Hold, G.L.; Flint, H.J. The gut microbiota, bacterial metabolites and colorectal cancer. Nat. Rev. Microbiol. 2014, 12, 661-672. [CrossRef]

82. Koh, A.; De Vadder, F.; Kovatcheva-Datchary, P.; Bäckhed, F. From dietary fiber to host physiology: Short-chain fatty acids as key bacterial metabolites. Cell 2016, 165, 1332-1345. [CrossRef]

83. Markowiak-Kopeć, P.; Sliżewska, K. The Effect of Probiotics on the Production of Short-Chain Fatty Acids by Human Intestinal Microbiome. Nutrients 2020, 12, 1107. [CrossRef]

84. Rey, F.E.; Faith, J.J.; Bain, J.; Muehlbauer, M.J.; Stevens, R.D.; Newgard, C.B.; Gordon, J.I. Dissecting the in vivo metabolic potential of two human gut acetogens. J. Biol. Chem. 2010, 285, 22082-22090. [CrossRef]

85. Miquel, S.; Martin, R.; Rossi, O.; Bermudez-Humaran, L.; Chatel, J.; Sokol, H.; Thomas, M.; Wells, J.; Langella, P. Faecalibacterium prausnitzii and human intestinal health. Curr. Opin. Microbiol. 2013, 16, 255-261. [CrossRef] [PubMed]

86. Duncan, S.H.; Hold, G.L.; Barcenilla, A.; Stewart, C.S.; Flint, H.J. Roseburia intestinalis sp. Nov., a novel saccharolytic, butyrate-producing bacterium from human faeces. Int. J. Syst. Evol. Microbiol. 2002, 52, 1615-1620. [PubMed]

87. Rossi, M.; Amaretti, A.; Raimondi, S. Folate production by probiotic bacteria. Nutrients 2011, 3, 118-134. [CrossRef] [PubMed]

88. Gu, Q.; Li, P. Biosynthesis of vitamins by probiotic bacteria. Probiotics Prebiotics Human Nutrition and Health; InTechOpen: London, UK, 2016.

89. Fahey, R.C.; Sundquist, A.R. Evolution of glutathione metabolism. Adv. Enzymol. Relat. Areas Mol. Biol 1991, $64,53$. 
90. Newton, G.L.; Arnold, K.; Price, M.S.; Sherrill, C.; Delcardayre, S.B.; Aharonowitz, Y.; Cohen, G.; Davies, J.; Fahey, R.C.; Davis, C. Distribution of thiols in microorganisms: Mycothiol is a major thiol in most actinomycetes. J. Bacteriol. 1996, 178, 1990-1995. [CrossRef]

91. Gopal, S.; Borovok, I.; Ofer, A.; Yanku, M.; Cohen, G.; Goebel, W.; Kreft, J.; Aharonowitz, Y. A multidomain fusion protein in Listeria monocytogenes catalyzes the two primary activities for glutathione biosynthesis. $J$. Bacteriol. 2005, 187, 3839-3847. [CrossRef]

92. Saldanha, D.; Kumar, N.; Ryali, V.; Srivastava, K.; Pawar, A. Serum serotonin abnormality in depression. Med. J. Armed Forces India 2009, 65, 108-112. [CrossRef]

93. Pan, J.-X.; Xia, J.-J.; Deng, F.-L.; Liang, W.-W.; Wu, J.; Yin, B.-M.; Dong, M.-X.; Chen, J.-J.; Ye, F.; Wang, H.-Y. Diagnosis of major depressive disorder based on changes in multiple plasma neurotransmitters: A targeted metabolomics study. Transl. Psychiatry 2018, 8, 1-10. [CrossRef]

94. Zheng, P.; Fang, Z.; Xu, X.-J.; Liu, M.-L.; Du, X.; Zhang, X.; Wang, H.; Zhou, J.; Xie, P. Metabolite signature for diagnosing major depressive disorder in peripheral blood mononuclear cells. J. Affect. Disord. 2016, 195, 75-81. [CrossRef]

95. Zhao, L.; Zheng, S.; Su, G.; Lu, X.; Yang, J.; Xiong, Z.; Wu, C. In vivo study on the neurotransmitters and their metabolites change in depressive disorder rat plasma by ultra high performance liquid chromatography coupled to tandem mass spectrometry. J. Chromatogr. B 2015, 988, 59-65. [CrossRef]

96. Madeira, C.; Vargas-Lopes, C.; Brandão, C.O.; Reis, T.; Laks, J.; Panizzutti, R.; Ferreira, S.T. Elevated glutamate and glutamine levels in the cerebrospinal fluid of patients with probable Alzheimer's disease and depression. Front. Psychiatry 2018, 9, 561. [CrossRef] [PubMed]

97. Inoshita, M.; Umehara, H.; Watanabe, S.-Y.; Nakataki, M.; Kinoshita, M.; Tomioka, Y.; Tajima, A.; Numata, S.; Ohmori, T. Elevated peripheral blood glutamate levels in major depressive disorder. Neuropsychiatr. Dis. Treat. 2018, 14, 945. [CrossRef] [PubMed]

98. Zheng, S.; Yu, M.; Lu, X.; Huo, T.; Ge, L.; Yang, J.; Wu, C.; Li, F. Urinary metabonomic study on biochemical changes in chronic unpredictable mild stress model of depression. Clin. Chim. Acta 2010, 411, 204-209. [CrossRef] [PubMed]

99. Shao, W.-H.; Fan, S.-H.; Lei, Y.; Yao, G.-E.; Chen, J.-J.; Zhou, J.; Xu, H.-B.; Liu, H.-P.; Wu, B.; Zheng, P. Metabolomic identification of molecular changes associated with stress resilience in the chronic mild stress rat model of depression. Metabolomics 2013, 9, 433-443. [CrossRef]

100. Ogawa, S.; Fujii, T.; Koga, N.; Hori, H.; Teraishi, T.; Hattori, K.; Noda, T.; Higuchi, T.; Motohashi, N.; Kunugi, H. Plasma L-tryptophan concentration in major depressive disorder: New data and meta-analysis. J. Clin. Psychiatry 2014, 75, 906-915. [CrossRef]

101. Ogyu, K.; Kubo, K.; Noda, Y.; Iwata, Y.; Tsugawa, S.; Omura, Y.; Wada, M.; Tarumi, R.; Plitman, E.; Moriguchi, S. Kynurenine pathway in depression: A systematic review and meta-analysis. Neurosci. Biobehav. Rev. 2018, 90, 16-25. [CrossRef]

102. Bryleva, E.Y.; Brundin, L. Kynurenine pathway metabolites and suicidality. Neuropharmacology 2017, 112, 324-330. [CrossRef]

103. Jaglin, M.; Rhimi, M.; Philippe, C.; Pons, N.; Bruneau, A.; Goustard, B.; Daugé, V.; Maguin, E.; Naudon, L.; Rabot, S. Indole, a signaling molecule produced by the gut microbiota, negatively impacts emotional behaviors in rats. Front. Neurosci. 2018, 12, 216. [CrossRef]

104. Skonieczna-Żydecka, K.; Grochans, E.; Maciejewska, D.; Szkup, M.; Schneider-Matyka, D.; Jurczak, A.; Łoniewski, I.; Kaczmarczyk, M.; Marlicz, W.; Czerwińska-Rogowska, M. Faecal short chain fatty acids profile is changed in Polish depressive women. Nutrients 2018, 10, 1939. [CrossRef]

105. Bottiglieri, T.; Laundy, M.; Crellin, R.; Toone, B.K.; Carney, M.W.; Reynolds, E.H. Homocysteine, folate, methylation, and monoamine metabolism in depression. J. Neurol. Neurosurg. Psychiatry 2000, 69, $228-232$. [CrossRef]

106. Gawryluk, J.W.; Wang, J.-F.; Andreazza, A.C.; Shao, L.; Young, L.T. Decreased levels of glutathione, the major brain antioxidant, in post-mortem prefrontal cortex from patients with psychiatric disorders. Int. J. Neuropsychopharmacol. 2011, 14, 123-130. [CrossRef] [PubMed]

107. Strandwitz, P. Neurotransmitter modulation by the gut microbiota. Brain Res. 2018, 1693, 128-133. [CrossRef] [PubMed]

108. Smith, K.; Fairburn, C.; Cowen, P. Relapse of depression after rapid depletion of tryptophan. Lancet 1997, 349, 915-919. [CrossRef] 
109. Cowen, P.J.; Browning, M. What has serotonin to do with depression? World Psychiatry 2015, 14, 158. [CrossRef]

110. Lund, M.L.; Egerod, K.L.; Engelstoft, M.S.; Dmytriyeva, O.; Theodorsson, E.; Patel, B.A.; Schwartz, T.W. Enterochromaffin 5-HT cells-A major target for GLP-1 and gut microbial metabolites. Mol. Metab. 2018, 11, 70-83. [CrossRef]

111. Williams, B.B.; Van Benschoten, A.H.; Cimermancic, P.; Donia, M.S.; Zimmermann, M.; Taketani, M.; Ishihara, A.; Kashyap, P.C.; Fraser, J.S.; Fischbach, M.A. Discovery and characterization of gut microbiota decarboxylases that can produce the neurotransmitter tryptamine. Cell Host Microbe 2014, 16, 495-503. [CrossRef]

112. Wikoff, W.R.; Anfora, A.T.; Liu, J.; Schultz, P.G.; Lesley, S.A.; Peters, E.C.; Siuzdak, G. Metabolomics analysis reveals large effects of gut microflora on mammalian blood metabolites. Proc. Natl. Acad. Sci. USA 2009, 106, 3698-3703. [CrossRef]

113. Steffens, D.C.; Jiang, W.; Krishnan, K.R.R.; Karoly, E.D.; Mitchell, M.W.; O'Connor, C.M.; Kaddurah-Daouk, R. Metabolomic differences in heart failure patients with and without major depression. J. Geriatr. Psychiatry Neurol. 2010, 23, 138-146. [CrossRef]

114. Chen, J.-J.; Xie, J.; Li, W.-W.; Bai, S.-J.; Wang, W.; Zheng, P.; Xie, P. Age-specific urinary metabolite signatures and functions in patients with major depressive disorder. Aging 2019, 11, 6626. [CrossRef]

115. Martins-de-Souza, D. Proteomics, metabolomics, and protein interactomics in the characterization of the molecular features of major depressive disorder. Dialogues Clin. Neurosci. 2014, 16, 63.

116. Belujon, P.; Grace, A.A. Dopamine system dysregulation in major depressive disorders. Int. J. Neuropsychopharmacol. 2017, 20, 1036-1046. [CrossRef] [PubMed]

117. Shen, L.-H.; Liao, M.-H.; Tseng, Y.-C. Recent advances in imaging of dopaminergic neurons for evaluation of neuropsychiatric disorders. J. Biomed. Biotechnol. 2012, 2012, 1-14. [CrossRef] [PubMed]

118. Sarchiapone, M.; Carli, V.; Camardese, G.; Cuomo, C.; Di Giuda, D.; Calcagni, M.-L.; Focacci, C.; De Risio, S. Dopamine transporter binding in depressed patients with anhedonia. Psychiatry Res. Neuroimaging 2006, 147, 243-248. [CrossRef] [PubMed]

119. Yadid, G.; Friedman, A. Dynamics of the dopaminergic system as a key component to the understanding of depression. Prog. Brain Res. 2008, 172, 265-286. [PubMed]

120. Willner, P.; Hale, A.S.; Argyropoulos, S. Dopaminergic mechanism of antidepressant action in depressed patients. J. Affect. Disord. 2005, 86, 37-45. [CrossRef]

121. Stahl, S.M. Essential Psychopharmacology: Neuroscientific Basis and Practical Applications; Cambridge University Press: Cambridge, UK, 2000.

122. Fidalgo, T.M.; Morales-Quezada, J.L.; Muzy, G.S.; Chiavetta, N.M.; Mendonca, M.E.; Santana, M.V.; Goncalves, O.F.; Brunoni, A.R.; Fregni, F. Biological Markers in Noninvasive Brain Stimulation Trials in Major Depressive Disorder. J. ECT 2013, 30, 47-61. [CrossRef]

123. Kram, M.L.; Kramer, G.L.; Ronan, P.J.; Steciuk, M.; Petty, F. Dopamine receptors and learned helplessness in the rat: An autoradiographic study. Prog. Neuro-Psychopharmacol. Biol. Psychiatry 2002, 26, 639-645. [CrossRef]

124. Maj, J.; Rogóż, Z.; Margas, W.; Kata, M.; Dziedzicka-Wasylewska, M. The effect of repeated treatment with pramipexole on the central dopamine D 3 system. J. Neural Transm. 2000, 107, 1369-1379.

125. González-Arancibia, C.; Urrutia-Piñones, J.; Illanes-González, J.; Martinez-Pinto, J.; Sotomayor-Zárate, R.; Julio-Pieper, M.; Bravo, J.A. Do your gut microbes affect your brain dopamine? Psychopharmacology 2019, 236, 1-12. [CrossRef]

126. Sudo, N.; Chida, Y.; Aiba, Y.; Sonoda, J.; Oyama, N.; Yu, X.N.; Kubo, C.; Koga, Y. Postnatal microbial colonization programs the hypothalamic-pituitary-adrenal system for stress response in mice. J. Physiol. 2004, 558, 263-275. [CrossRef]

127. Rogers, G.; Keating, D.; Young, R.; Wong, M.; Licinio, J.; Wesselingh, S. From gut dysbiosis to altered brain function and mental illness: Mechanisms and pathways. Mol. Psychiatry 2016, 21, 738-748. [CrossRef] [PubMed]

128. Bonaz, B.; Bazin, T.; Pellissier, S. The vagus nerve at the interface of the microbiota-gut-brain axis. Front Neurosci. 2018, 12, 49. [CrossRef] [PubMed] 
129. Bravo, J.A.; Forsythe, P.; Chew, M.V.; Escaravage, E.; Savignac, H.M.; Dinan, T.G.; Bienenstock, J.; Cryan, J.F. Ingestion of Lactobacillus strain regulates emotional behavior and central GABA receptor expression in a mouse via the vagus nerve. Proc. Natl. Acad. Sci. USA 2011, 108, 16050-16055. [CrossRef] [PubMed]

130. Han, W.; Tellez, L.A.; Perkins, M.H.; Perez, I.O.; Qu, T.; Ferreira, J.; Ferreira, T.L.; Quinn, D.; Liu, Z.-W.; Gao, X.-B. A neural circuit for gut-induced reward. Cell 2018, 175, 665.e623-678.e623. [CrossRef] [PubMed]

131. Freestone, P.P.; Williams, P.H.; Haigh, R.D.; Maggs, A.F.; Neal, C.P.; Lyte, M. Growth stimulation of intestinal commensal Escherichia coli by catecholamines: A possible contributory factor in trauma-induced sepsis. Shock 2002, 18, 465-470. [CrossRef]

132. Jacobson, L.H.; Vlachou, S.; Slattery, D.A.; Li, X.; Cryan, J.F. The gamma-aminobutyric acid B receptor in depression and reward. Biol. Psychiatry 2018, 83, 963-976. [CrossRef]

133. Pibiri, F.; Carboni, G.; Carai, M.A.; Gessa, G.L.; Castelli, M.P. Up-regulation of GABAB receptors by chronic administration of the GABAB receptor antagonist SCH 50,911. Eur. J. Pharmacol. 2005, 515, 94-98. [CrossRef]

134. Malcangio, M.; Da Silva, H.; Bowery, N.G. Plasticity of GABAB receptor in rat spinal cord detected by autoradiography. Eur. J. Pharmacol. 1993, 250, 153-156. [CrossRef]

135. Mombereau, C.; Kaupmann, K.; Froestl, W.; Sansig, G.; van der Putten, H.; Cryan, J.F. Genetic and pharmacological evidence of a role for GABA B receptors in the modulation of anxiety-and antidepressant-like behavior. Neuropsychopharmacology 2004, 29, 1050-1062. [CrossRef]

136. Tao, R.; Auerbach, S.B. Regulation of serotonin release by GABA and excitatory amino acids. J. Psychopharmacol. 2000, 14, 100-113. [CrossRef]

137. Matsumoto, M.; Kibe, R.; Ooga, T.; Aiba, Y.; Sawaki, E.; Koga, Y.; Benno, Y. Cerebral low-molecular metabolites influenced by intestinal microbiota: A pilot study. Front. Syst. Neurosci. 2013, 7, 9. [CrossRef] [PubMed]

138. Barrett, E.; Ross, R.; O'toole, P.; Fitzgerald, G.; Stanton, C. $\gamma$-Aminobutyric acid production by culturable bacteria from the human intestine. J. Appl. Microbiol. 2012, 113, 411-417. [CrossRef] [PubMed]

139. Auteri, M.; Zizzo, M.G.; Serio, R. GABA and GABA receptors in the gastrointestinal tract: From motility to inflammation. Pharmacol. Res. 2015, 93, 11-21. [CrossRef] [PubMed]

140. Thwaites, D.T.; Basterfield, L.; McCleave, P.M.; Carter, S.M.; Simmons, N.L. Gamma-aminobutyric acid (GABA) transport across human intestinal epithelial (Caco-2) cell monolayers. Br. J. Pharmacol. 2000, 129, 457-464. [CrossRef]

141. Hyland, N.P.; Cryan, J.F. A gut feeling about GABA: Focus on GABAB receptors. Front. Pharmacol. 2010, 1, 124. [CrossRef]

142. Zhang, Y.; Yuan, S.; Pu, J.; Yang, L.; Zhou, X.; Liu, L.; Jiang, X.; Zhang, H.; Teng, T.; Tian, L. Integrated metabolomics and proteomics analysis of hippocampus in a rat model of depression. Neuroscience 2018, 371, 207-220. [CrossRef]

143. Sanacora, G.; Treccani, G.; Popoli, M. Towards a glutamate hypothesis of depression: An emerging frontier of neuropsychopharmacology for mood disorders. Neuropharmacology 2012, 62, 63-77. [CrossRef]

144. Liu, L.; Zhou, X.; Zhang, Y.; Liu, Y.; Yang, L.; Pu, J.; Zhu, D.; Zhou, C.; Xie, P. The identification of metabolic disturbances in the prefrontal cortex of the chronic restraint stress rat model of depression. Behav. Brain Res. 2016, 305, 148-156. [CrossRef]

145. Kumar, B.H.; Mishra, S.K.; Rana, P.; Singh, S.; Khushu, S. Neurodegenerative evidences during early onset of depression in CMS rats as detected by proton magnetic resonance spectroscopy at 7 T. Behav. Brain Res. 2012, 232, 53-59. [CrossRef]

146. Medina, A.; Burke, S.; Thompson, R.C.; Bunney, W., Jr.; Myers, R.M.; Schatzberg, A.; Akil, H.; Watson, S.J. Glutamate transporters: A key piece in the glutamate puzzle of major depressive disorder. J. Psychiatr. Res. 2013, 47, 1150-1156. [CrossRef]

147. Zink, M.; Vollmayr, B.; Gebicke-Haerter, P.; Henn, F. Reduced expression of glutamate transporters vGluT1, EAAT2 and EAAT4 in learned helpless rats, an animal model of depression. Neuropharmacology 2010, 58, 465-473. [CrossRef] [PubMed]

148. Deutschenbaur, L.; Beck, J.; Kiyhankhadiv, A.; Mühlhauser, M.; Borgwardt, S.; Walter, M.; Hasler, G.; Sollberger, D.; Lang, U.E. Role of calcium, glutamate and NMDA in major depression and therapeutic application. Prog. Neuro Psychopharmacol. Biol. Psychiatry 2016, 64, 325-333. [CrossRef] [PubMed]

149. Hashimoto, K.; Bruno, D.; Nierenberg, J.; Marmar, C.; Zetterberg, H.; Blennow, K.; Pomara, N. Abnormality in glutamine-glutamate cycle in the cerebrospinal fluid of cognitively intact elderly individuals with major depressive disorder: A 3-year follow-up study. Transl. Psychiatry 2016, 6, e744. [CrossRef] [PubMed] 
150. Yoon, S.J.; Lyoo, I.K.; Haws, C.; Kim, T.-S.; Cohen, B.M.; Renshaw, P.F. Decreased glutamate/glutamine levels may mediate cytidine's efficacy in treating bipolar depression: A longitudinal proton magnetic resonance spectroscopy study. Neuropsychopharmacology 2009, 34, 1810-1818. [CrossRef]

151. Gros, D.F.; Antony, M.M.; McCabe, R.E.; Swinson, R.P. Frequency and severity of the symptoms of irritable bowel syndrome across the anxiety disorders and depression. J. Anxiety Disord. 2009, 23, 290-296. [CrossRef]

152. Mazzoli, R.; Riedel, K.; Pessione, E. Bioactive compounds from microbes. Front. Microbiol. 2017,8 , 392. [CrossRef]

153. Sengupta, S.; Ghosh, S.; Nagaraja, V. Moonlighting function of glutamate racemase from Mycobacterium tuberculosis: Racemization and DNA gyrase inhibition are two independent activities of the enzyme. Microbiology 2008, 154, 2796-2803. [CrossRef]

154. Mathews, G.C.; Diamond, J.S. Neuronal glutamate uptake contributes to GABA synthesis and inhibitory synaptic strength. J. Neurosci. 2003, 23, 2040-2048. [CrossRef]

155. Lyte, M. Probiotics function mechanistically as delivery vehicles for neuroactive compounds: Microbial endocrinology in the design and use of probiotics. Bioessays 2011, 33, 574-581. [CrossRef]

156. Pu, J.; Liu, Y.; Zhang, H.; Tian, L.; Gui, S.; Yu, Y.; Chen, X.; Chen, Y.; Yang, L.; Ran, Y. An integrated meta-analysis of peripheral blood metabolites and biological functions in major depressive disorder. Mol. Psychiatry 2020, 1-12. [CrossRef]

157. Baranyi, A.; Amouzadeh-Ghadikolai, O.; von Lewinski, D.; Rothenhäusler, H.-B.; Theokas, S.; Robier, C.; Mangge, H.; Reicht, G.; Hlade, P.; Meinitzer, A. Branched-chain amino acids as new biomarkers of major depression-a novel neurobiology of mood disorder. PLoS ONE 2016, 11, e0160542. [CrossRef] [PubMed]

158. Jianguo, L.; Xueyang, J.; Cui, W.; Changxin, W.; Xuemei, Q. Altered gut metabolome contributes to depression-like behaviors in rats exposed to chronic unpredictable mild stress. Transl. Psychiatry 2019, 9, 1-14.

159. Ozden, A.; Angelos, H.; Feyza, A.; Elizabeth, W.; John, P. Altered plasma levels of arginine metabolites in depression. J. Psychiatr. Res. 2020, 120, 21-28. [CrossRef] [PubMed]

160. Hess, S.; Baker, G.; Gyenes, G.; Tsuyuki, R.; Newman, S.; Le Melledo, J.-M. Decreased serum L-arginine and L-citrulline levels in major depression. Psychopharmacology 2017, 234, 3241-3247. [CrossRef]

161. Lu, Y.-R.; Fu, X.-Y.; Shi, L.-G.; Jiang, Y.; Wu, J.-L.; Weng, X.-J.; Wang, Z.-P.; Wu, X.-Y.; Lin, Z.; Liu, W.-B. Decreased plasma neuroactive amino acids and increased nitric oxide levels in melancholic major depressive disorder. BMC Psychiatry 2014, 14, 123. [CrossRef]

162. Zhou, X.; Liu, L.; Zhang, Y.; Pu, J.; Yang, L.; Zhou, C.; Yuan, S.; Zhang, H.; Xie, P. Metabolomics identifies perturbations in amino acid metabolism in the prefrontal cortex of the learned helplessness rat model of depression. Neuroscience 2017, 343, 1-9. [CrossRef]

163. Mitani, H.; Shirayama, Y.; Yamada, T.; Maeda, K.; Ashby, C.R., Jr.; Kawahara, R. Correlation between plasma levels of glutamate, alanine and serine with severity of depression. Prog. Neuro Psychopharmacol. Biol. Psychiatry 2006, 30, 1155-1158. [CrossRef]

164. Li, J.; Tang, G.; Cheng, K.; Yang, D.; Chen, G.; Liu, Z.; Zhang, R.; Zhou, J.; Fang, L.; Fang, Z. Peripheral blood mononuclear cell-based metabolomic profiling of a chronic unpredictable mild stress rat model of depression. Mol. Biosyst. 2014, 10, 2994-3001. [CrossRef]

165. Zhou, Y.-F.; Feng, L.; Liu, X.-M.; Tao, X.; Wang, L.-S.; Zhang, M.-D.; Wang, Z.; Chen, S.-G.; Chang, Q. Urinary metabolic disturbance in the olfactory bulbectomized rats and the modulatory effects of fluoxetine. Life Sci. 2019, 234, 116751. [CrossRef]

166. Zhang, F.; Jia, Z.; Gao, P.; Kong, H.; Li, X.; Lu, X.; Wu, Y.; Xu, G. Metabonomics study of urine and plasma in depression and excess fatigue rats by ultra fast liquid chromatography coupled with ion trap-time of flight mass spectrometry. Mol. Biosyst. 2010, 6, 852-861. [CrossRef]

167. Liu, X.J.; Li, Z.Y.; Li, Z.F.; Gao, X.X.; Zhou, Y.Z.; Sun, H.F.; Zhang, L.Z.; Guo, X.Q.; Du, G.H.; Qin, X.M. Urinary metabonomic study using a CUMS rat model of depression. Magn. Reson. Chem. 2012, 50, 187-192. [CrossRef] [PubMed]

168. Xiong, Z.; Yang, J.; Huang, Y.; Zhang, K.; Bo, Y.; Lu, X.; Su, G.; Ma, J.; Yang, J.; Zhao, L. Serum metabonomics study of anti-depressive effect of Xiao-Chai-Hu-Tang on rat model of chronic unpredictable mild stress. J. Chromatogr. B 2016, 1029, 28-35. [CrossRef] [PubMed] 
169. Hashimoto, K.; Yoshida, T.; Ishikawa, M.; Fujita, Y.; Niitsu, T.; Nakazato, M.; Watanabe, H.; Sasaki, T.; Shiina, A.; Hashimoto, T. Increased serum levels of serine enantiomers in patients with depression. Acta Neuropsychiatr. 2016, 28, 173-178. [CrossRef] [PubMed]

170. Zhou, Y.; Zheng, W.; Liu, W.; Wang, C.; Zhan, Y.; Li, H.; Chen, L.; Ning, Y. Cross-sectional relationship between kynurenine pathway metabolites and cognitive function in major depressive disorder. Psychoneuroendocrinology 2019, 101, 72-79. [CrossRef] [PubMed]

171. Myint, A.-M.; Kim, Y.K.; Verkerk, R.; Scharpé, S.; Steinbusch, H.; Leonard, B. Kynurenine pathway in major depression: Evidence of impaired neuroprotection. J. Affect. Disord. 2007, 98, 143-151. [CrossRef]

172. Islam, M.R.; Ali, S.; Karmoker, J.R.; Kadir, M.F.; Ahmed, M.U.; Nahar, Z.; Islam, S.M.A.; Islam, M.S.; Hasnat, A.; Islam, M.S. Evaluation of serum amino acids and non-enzymatic antioxidants in drug-naïve first-episode major depressive disorder. BMC Psychiatry 2020, 20, 1-8. [CrossRef]

173. Murakami, T.; Furuse, M. The impact of taurine-and beta-alanine-supplemented diets on behavioral and neurochemical parameters in mice: Antidepressant versus anxiolytic-like effects. Amino Acids 2010, 39, 427-434. [CrossRef]

174. Dong, D.; Lei, T.; Song, M.; Ma, L.; Zhao, H. The antidepressant effects of L-arginine on chronic mild stress-induced depression by augmenting the expression of brain-derived neurotrophic factor in rats. In Brain Reseaarch Bulletin; Elsevier: Amsterdam, The Netherlands, 2020.

175. Son, H.; Baek, J.H.; Go, B.S.; Jung, D.-H.; Sontakke, S.B.; Chung, H.J.; Lee, D.H.; Roh, G.S.; Kang, S.S.; Cho, G.J. Glutamine has antidepressive effects through increments of glutamate and glutamine levels and glutamatergic activity in the medial prefrontal cortex. Neuropharmacology 2018, 143, 143-152. [CrossRef]

176. Walker, A.K.; Wing, E.E.; Banks, W.A.; Dantzer, R. Leucine competes with kynurenine for blood-to-brain transport and prevents lipopolysaccharide-induced depression-like behavior in mice. Mol. Psychiatry 2019, 24, 1523-1532. [CrossRef]

177. De Berardis, D.; Orsolini, L.; Serroni, N.; Girinelli, G.; Iasevoli, F.; Tomasetti, C.; de Bartolomeis, A.; Mazza, M.; Valchera, A.; Fornaro, M. A comprehensive review on the efficacy of S-adenosyl-L-methionine in major depressive disorder. Cns Neurol. Disord. Drug Targets 2016, 15, 35-44. [CrossRef]

178. Malkesman, O.; Austin, D.R.; Tragon, T.; Wang, G.; Rompala, G.; Hamidi, A.B.; Cui, Z.; Young, W.S.; Nakazawa, K.; Zarate, C.A., Jr. Acute D-serine treatment produces antidepressant-like effects in rodents. Int. J. Neuropsychopharmacol. 2012, 15, 1135-1148. [CrossRef] [PubMed]

179. Otte, D.-M.; de Arellano, M.L.B.; Bilkei-Gorzo, A.; Albayram, Ö.; Imbeault, S.; Jeung, H.; Alferink, J.; Zimmer, A. Effects of chronic D-serine elevation on animal models of depression and anxiety-related behavior. PLOS ONE 2013, 8, e67131. [CrossRef] [PubMed]

180. Muszyńska, B.; Łojewski, M.; Rojowski, J.; Opoka, W.; Sułkowska-Ziaja, K. Surowce naturalne mające znaczenie w profilaktyce i wspomagajace leczenie depresji. Psychiatr. Pol. 2015, 49, 435-453. [CrossRef] [PubMed]

181. Alabsi, A.; Khoudary, A.C.; Abdelwahed, W. The antidepressant effect of L-tyrosine-loaded nanoparticles: Behavioral aspects. Ann. Neurosci. 2016, 23, 89-99. [CrossRef]

182. Chen, G.; Yang, D.; Yang, Y.; Li, J.; Cheng, K.; Tang, G.; Zhang, R.; Zhou, J.; Li, W.; Liu, Z. Amino acid metabolic dysfunction revealed in the prefrontal cortex of a rat model of depression. Behav. Brain Res. 2015, 278, 286-292. [CrossRef]

183. Baranyi, A.; Meinitzer, A.; Rothenhäusler, H.-B.; Amouzadeh-Ghadikolai, O.; Lewinski, D.V.; Breitenecker, R.J.; Herrmann, M. Metabolomics approach in the investigation of depression biomarkers in pharmacologically induced immune-related depression. PLoS ONE 2018, 13, e0208238. [CrossRef]

184. Joynt, K.E.; Whellan, D.J.; O'connor, C.M. Depression and cardiovascular disease: Mechanisms of interaction. Biol. Psychiatry 2003, 54, 248-261. [CrossRef]

185. Clarke, G.; Grenham, S.; Scully, P.; Fitzgerald, P.; Moloney, R.; Shanahan, F.; Dinan, T.; Cryan, J. The microbiome-gut-brain axis during early life regulates the hippocampal serotonergic system in a sex-dependent manner. Mol. Psychiatry 2013, 18, 666-673. [CrossRef]

186. Aagaard, K.; Ma, J.; Antony, K.M.; Ganu, R.; Petrosino, J.; Versalovic, J. The placenta harbors a unique microbiome. Sci. Transl. Med. 2014, 6, ra237-ra265. [CrossRef]

187. Fernández, L.; Langa, S.; Martín, V.; Maldonado, A.; Jiménez, E.; Martín, R.; Rodríguez, J.M. The human milk microbiota: Origin and potential roles in health and disease. Pharmacol. Res. 2013, 69, 1-10. [CrossRef] 
188. Mir, H.-D.; Milman, A.; Monnoye, M.; Douard, V.; Philippe, C.; Aubert, A.; Castanon, N.; Vancassel, S.; Guérineau, N.C.; Naudon, L. The gut microbiota metabolite indole increases emotional responses and adrenal medulla activity in chronically stressed male mice. Psychoneuroendocrinology 2020, 119, 104750. [CrossRef] [PubMed]

189. Buckley, M.M.; O’Brien, R.; Brosnan, E.; Ross, R.P.; Stanton, C.; Buckley, J.M.; O’Malley, D. Glucagon-Like Peptide-1 Secreting L-Cells Coupled to Sensory Nerves Translate Microbial Signals to the Host Rat Nervous System. Front. Cell. Neurosci. 2020, 14, 95. [CrossRef] [PubMed]

190. Medvedev, A.; Kopylov, A.; Buneeva, O.; Kurbatov, L.; Tikhonova, O.; Ivanov, A.; Zgoda, V. A Neuroprotective Dose of Isatin Causes Multilevel Changes Involving the Brain Proteome: Prospects for Further Research. Int. J. Mol. Sci. 2020, 21, 4187. [CrossRef] [PubMed]

191. Cervantes-Barragan, L.; Chai, J.N.; Tianero, M.D.; Di Luccia, B.; Ahern, P.P.; Merriman, J.; Cortez, V.S.; Caparon, M.G.; Donia, M.S.; Gilfillan, S. Lactobacillus reuteri induces gut intraepithelial CD4+ CD8 $\alpha \alpha+\mathrm{T}$ cells. Science 2017, 357, 806-810. [CrossRef]

192. Wong, C.B.; Tanaka, A.; Kuhara, T.; Xiao, J.-Z. Potential Effects of Indole-3-Lactic Acid, a Metabolite of Human Bifidobacteria, on NGF-Induced Neurite Outgrowth in PC12 Cells. Microorganisms 2020, 8, 398. [CrossRef]

193. Xiao, H.-W.; Cui, M.; Li, Y.; Dong, J.-L.; Zhang, S.-Q.; Zhu, C.-C.; Jiang, M.; Zhu, T.; Wang, B.; Wang, H.-C. Gut microbiota-derived indole 3-propionic acid protects against radiation toxicity via retaining acyl-CoA-binding protein. Microbiome 2020, 8, 1-17. [CrossRef]

194. Zhao, Z.-H.; Xin, F.-Z.; Xue, Y.; Hu, Z.; Han, Y.; Ma, F.; Zhou, D.; Liu, X.-L.; Cui, A.; Liu, Z. Indole-3-propionic acid inhibits gut dysbiosis and endotoxin leakage to attenuate steatohepatitis in rats. Exp. Mol. Med. 2019, 51, 1-14. [CrossRef]

195. Mimori, S.; Kawada, K.; Saito, R.; Takahashi, M.; Mizoi, K.; Okuma, Y.; Hosokawa, M.; Kanzaki, T. Indole-3-propionic acid has chemical chaperone activity and suppresses endoplasmic reticulum stress-induced neuronal cell death. Biochem. Biophys. Res. Commun. 2019, 517, 623-628. [CrossRef]

196. Zhang, P.; Jin, T.; Kumar Sahu, S.; Xu, J.; Shi, Q.; Liu, H.; Wang, Y. The distribution of tryptophan-dependent indole-3-acetic acid synthesis pathways in bacteria unraveled by large-scale genomic analysis. Molecules 2019, 24, 1411. [CrossRef]

197. Luo, J.; Zhou, J.-J.; Zhang, J.-Z. Aux/IAA gene family in plants: Molecular structure, regulation, and function. Int. J. Mol. Sci. 2018, 19, 259. [CrossRef]

198. Greenhut, I.V.; Slezak, B.L.; Leveau, J.H. iac gene expression in the indole-3-acetic acid-degrading soil bacterium Enterobacter soli LF7. Appl. Environ. Microbiol. 2018, 84. [CrossRef] [PubMed]

199. Lin, Y.-T.; Wu, P.-H.; Lee, H.-H.; Mubanga, M.; Chen, C.-S.; Kuo, M.-C.; Chiu, Y.-W.; Kuo, P.-L.; Hwang, S.-J. Indole-3 acetic acid increased risk of impaired cognitive function in patients receiving hemodialysis. Neurotoxicology 2019, 73, 85-91. [CrossRef] [PubMed]

200. Réus, G.Z.; Jansen, K.; Titus, S.; Carvalho, A.F.; Gabbay, V.; Quevedo, J. Kynurenine pathway dysfunction in the pathophysiology and treatment of depression: Evidences from animal and human studies. J. Psychiatr. Res. 2015, 68, 316-328. [CrossRef] [PubMed]

201. Baranyi, A.; Meinitzer, A.; Stepan, A.; Putz-Bankuti, C.; Breitenecker, R.J.; Stauber, R.; Kapfhammer, H.-P.; Rothenhäusler, H.-B. A biopsychosocial model of interferon-alpha-induced depression in patients with chronic hepatitis C infection. Psychother. Psychosom. 2013, 82, 332-340. [CrossRef]

202. Wigner, P.; Czarny, P.; Galecki, P.; Sliwinski, T. Oxidative and nitrosative stress as well as the tryptophan catabolites pathway in depressive disorders. Psychiatr. Danub. 2017, 29, 394-400. [CrossRef]

203. Maes, M.; Leonard, B.; Myint, A.; Kubera, M.; Verkerk, R. The new '5-HT'hypothesis of depression: Cell-mediated immune activation induces indoleamine 2, 3-dioxygenase, which leads to lower plasma tryptophan and an increased synthesis of detrimental tryptophan catabolites (TRYCATs), both of which contribute to the onset of depression. Prog. Neuro Psychopharmacol. Biol. Psychiatry 2011, 35, 702-721.

204. Wei, I.-H.; Chen, K.-T.; Tsai, M.-H.; Wu, C.-H.; Lane, H.-Y.; Huang, C.-C. Acute amino acid D-serine administration, similar to ketamine, produces antidepressant-like effects through identical mechanisms. J. Agric. Food Chem. 2017, 65, 10792-10803. [CrossRef]

205. MacKay, M.; Kravtsenyuk, M.; Thomas, R.; Mitchell, N.; Dursun, S.; Baker, G. Serine: Potential Therapeutic Agent and/or Biomarker in Schizophrenia and Depression? Front. Psychiatry 2019, 10, 25. [CrossRef]

206. Savitz, J. The kynurenine pathway: A finger in every pie. Mol. Psychiatry 2019, 25, 1-17. [CrossRef] 
207. Dai, Z.-L.; Wu, G.; Zhu, W.-Y. Amino acid metabolism in intestinal bacteria: Links between gut ecology and host health. Front Biosci. 2011, 16, 1768-1786. [CrossRef]

208. Kurnasov, O.; Jablonski, L.; Polanuyer, B.; Dorrestein, P.; Begley, T.; Osterman, A. Aerobic tryptophan degradation pathway in bacteria: Novel kynurenine formamidase. FEMS Microbiol. Lett. 2003, 227, $219-227$. [CrossRef]

209. Christiansen, C.B.; Gabe, M.B.N.; Svendsen, B.; Dragsted, L.O.; Rosenkilde, M.M.; Holst, J.J. The impact of short-chain fatty acids on GLP-1 and PYY secretion from the isolated perfused rat colon. Am. J. Physiol. Gastrointest. Liver Physiol. 2018, 315, G53-G65. [CrossRef] [PubMed]

210. Pascale, A.; Marchesi, N.; Marelli, C.; Coppola, A.; Luzi, L.; Govoni, S.; Giustina, A.; Gazzaruso, C. Microbiota and metabolic diseases. Endocrine 2018, 61, 357-371. [CrossRef] [PubMed]

211. Silva, Y.P.; Bernardi, A.; Frozza, R.L. The role of short-chain fatty acids from gut microbiota in gut-brain communication. Front. Endocrinol. 2020, 11, 25. [CrossRef]

212. Moretti, M.; Valvassori, S.S.; Varela, R.B.; Ferreira, C.L.; Rochi, N.; Benedet, J.; Scaini, G.; Kapczinski, F.; Streck, E.L.; Zugno, A.I. Behavioral and neurochemical effects of sodium butyrate in an animal model of mania. Behav. Pharmacol. 2011, 22, 766-772. [CrossRef]

213. Resende, W.R.; Valvassori, S.S.; Reus, G.Z.; Varela, R.B.; Arent, C.O.; Ribeiro, K.F.; Bavaresco, D.V.; Andersen, M.L.; Zugno, A.I.; Quevedo, J. Effects of sodium butyrate in animal models of mania and depression: Implications as a new mood stabilizer. Behav. Pharmacol. 2013, 24, 569-579. [CrossRef]

214. Jesulola, E.; Micalos, P.; Baguley, I.J. Understanding the pathophysiology of depression: From monoamines to the neurogenesis hypothesis model-are we there yet? Behav. Brain Res. 2018, 341, 79-90. [CrossRef]

215. El-Ansary, A.; Al-Ayadhi, L. Relative abundance of short chain and polyunsaturated fatty acids in propionic acid-induced autistic features in rat pups as potential markers in autism. Lipids Health Dis. 2014, 13, 140. [CrossRef]

216. Reigstad, C.S.; Salmonson, C.E.; Szurszewski, J.H.; Linden, D.R.; Sonnenburg, J.L.; Farrugia, G.; Kashyap, P.C. Gut microbes promote colonic serotonin production through an effect of short-chain fatty acids on enterochromaffin cells. FASEB J. 2015, 29, 1395-1403. [CrossRef]

217. El-Ansary, A.K.; Bacha, A.B.; Kotb, M. Etiology of autistic features: The persisting neurotoxic effects of propionic acid. J. Neuroinflamm. 2012, 9, 74. [CrossRef]

218. Sun, J.; Wang, F.; Hong, G.; Pang, M.; Xu, H.; Li, H.; Tian, F.; Fang, R.; Yao, Y.; Liu, J. Antidepressant-like effects of sodium butyrate and its possible mechanisms of action in mice exposed to chronic unpredictable mild stress. Neurosci. Lett. 2016, 618, 159-166. [CrossRef] [PubMed]

219. DeCastro, M.; Nankova, B.B.; Shah, P.; Patel, P.; Mally, P.V.; Mishra, R.; La Gamma, E.F. Short chain fatty acids regulate tyrosine hydroxylase gene expression through a cAMP-dependent signaling pathway. Mol. Brain Res. 2005, 142, 28-38. [CrossRef] [PubMed]

220. Feng, W.; Ao, H.; Peng, C. Gut microbiota, short-chain fatty acids, and herbal medicines. Front. Pharmacol. 2018, 9, 1354. [CrossRef] [PubMed]

221. Yamane, T.; Chen, X.; Ueda, S. Growth-associated production of poly (3-hydroxyvalerate) from n-pentanol by a methylotrophic bacterium, Paracoccus denitrificans. Appl. Environ. Microbiol. 1996, 62, 380-384. [CrossRef] [PubMed]

222. Macfarlane, G.; Cummings, J.; Allison, C. Protein degradation by human intestinal bacteria. Microbiology 1986, 132, 1647-1656. [CrossRef] [PubMed]

223. Cuthbert, B.N.; Insel, T.R. Toward the future of psychiatric diagnosis: The seven pillars of RDoC. BMC Med. 2013, 11, 126. [CrossRef] [PubMed]

224. Chan, M.K.; Gottschalk, M.G.; Haenisch, F.; Tomasik, J.; Ruland, T.; Rahmoune, H.; Guest, P.C.; Bahn, S. Applications of blood-based protein biomarker strategies in the study of psychiatric disorders. Prog. Neurobiol. 2014, 122, 45-72. [CrossRef]

225. Schmidt, H.D.; Shelton, R.C.; Duman, R.S. Functional biomarkers of depression: Diagnosis, treatment, and pathophysiology. Neuropsychopharmacology 2011, 36, 2375-2394. [CrossRef]

226. Miškulin, M. Vitamin B12 deficiency and depression in elderly: Cross-sectional study in Eastern Croatia. J. Health Sci. 2014, 4, 143-148. [CrossRef]

227. Park, Y.H.; Choi-Kwon, S.; Park, K.A.; Suh, M.; Jung, Y.S. Nutrient deficiencies and depression in older adults according to sex: A cross sectional study. Nurs. Health Sci. 2017, 19, 88-94. [CrossRef] 
228. LeBlanc, J.G.; Milani, C.; De Giori, G.S.; Sesma, F.; Van Sinderen, D.; Ventura, M. Bacteria as vitamin suppliers to their host: A gut microbiota perspective. Curr. Opin. Biotechnol. 2013, 24, 160-168. [CrossRef] [PubMed]

229. Rosenberg, J.; Ischebeck, T.; Commichau, F.M. Vitamin B6 metabolism in microbes and approaches for fermentative production. Biotechnol. Adv. 2017, 35, 31-40. [CrossRef] [PubMed]

230. Agrawal, S.; Agrawal, A.; Said, H.M. Biotin deficiency enhances the inflammatory response of human dendritic cells. Am. J. Physiol. Cell Physiol. 2016, 311, C386-C391. [CrossRef] [PubMed]

231. Alpert, J.E.; Fava, M. Nutrition and depression: The role of folate. Nutr. Rev. 1997, 55, 145-149. [CrossRef] [PubMed]

232. Owen, R. Augmenting antidepressant response with folates. Drugs Today 2013, 49, 791. [CrossRef] [PubMed]

233. Miller, A.L. The methylation, neurotransmitter, and antioxidant connections between folate and depression. Altern. Med. Rev. 2008, 13, 13.

234. Liu, J.J.; Green, P.; Mann, J.J.; Rapoport, S.I.; Sublette, M.E. Pathways of polyunsaturated fatty acid utilization: Implications for brain function in neuropsychiatric health and disease. Brain Res. 2015, 1597, 220-246. [CrossRef]

235. Druart, C.; Bindels, L.B.; Schmaltz, R.; Neyrinck, A.M.; Cani, P.D.; Walter, J.; Ramer-Tait, A.E.; Delzenne, N.M. Ability of the gut microbiota to produce PUFA-derived bacterial metabolites: Proof of concept in germ-free versus conventionalized mice. Mol. Nutr. Food Res. 2015, 59, 1603-1613. [CrossRef]

236. Costantini, L.; Molinari, R.; Farinon, B.; Merendino, N. Impact of omega-3 fatty acids on the gut microbiota. Int. J. Mol. Sci. 2017, 18, 2645. [CrossRef]

237. Robertson, R.C.; Oriach, C.S.; Murphy, K.; Moloney, G.M.; Cryan, J.F.; Dinan, T.G.; Ross, R.P.; Stanton, C. Omega-3 polyunsaturated fatty acids critically regulate behaviour and gut microbiota development in adolescence and adulthood. Brain Behav. Immun. 2017, 59, 21-37. [CrossRef]

238. Olvera, R.L.; Caetano, S.C.; Stanley, J.A.; Chen, H.-H.; Nicoletti, M.; Hatch, J.P.; Fonseca, M.; Pliszka, S.R.; Soares, J.C. Reduced medial prefrontal N-Acetyl-Aspartate levels in pediatric major depressive disorder: A multi-voxel in vivo1H spectroscopy study. Psychiatry Res. Neuroimaging 2010, 184, 71-76. [CrossRef] [PubMed]

239. Lefebvre, D.; Langevin, L.M.; Jaworska, N.; Harris, A.D.; Lebel, R.M.; Jasaui, Y.; Kirton, A.; Wilkes, T.C.; Sembo, M.; Swansburg, R. A pilot study of hippocampal N-acetyl-aspartate in youth with treatment resistant major depression. J. Affect. Disord. 2017, 207, 110-113. [CrossRef] [PubMed]

240. Janik, R.; Thomason, L.A.; Stanisz, A.M.; Forsythe, P.; Bienenstock, J.; Stanisz, G.J. Magnetic resonance spectroscopy reveals oral Lactobacillus promotion of increases in brain GABA, N-acetyl aspartate and glutamate. Neuroimage 2016, 125, 988-995. [CrossRef] [PubMed]

241. Mocking, R.; Assies, J.; Ruhé, H.; Schene, A. Focus on fatty acids in the neurometabolic pathophysiology of psychiatric disorders. J. Inherit. Metab. Dis. 2018, 41, 597-611. [CrossRef]

242. Wang, S.-M.; Han, C.; Lee, S.-J.; Patkar, A.A.; Masand, P.S.; Pae, C.-U. A review of current evidence for acetyl-1-carnitine in the treatment of depression. J. Psychiatr. Res. 2014, 53, 30-37. [CrossRef]

243. Jia, H.-M.; Li, Q.; Zhou, C.; Yu, M.; Yang, Y.; Zhang, H.-W.; Ding, G.; Shang, H.; Zou, Z.-M. Chronic unpredictive mild stress leads to altered hepatic metabolic profile and gene expression. Sci. Rep. 2016, 6, 23441. [CrossRef]

244. Lei, T.; Wang, Y.; Li, M.; Zhang, X.; Lv, C.; Jia, L.; Wang, J.; Lu, J. A comparative study of the main constituents and antidepressant effects of raw and vinegar-baked Bupleuri Radix in rats subjected to chronic unpredictable mild stress. RSC Adv. 2017, 7, 32652-32663. [CrossRef]

245. Gérard, P. Metabolism of cholesterol and bile acids by the gut microbiota. Pathogens 2014, 3, 14-24. [CrossRef]

246. Grudet, C.; Malm, J.; Westrin, Å.; Brundin, L. Suicidal patients are deficient in vitamin D, associated with a pro-inflammatory status in the blood. Psychoneuroendocrinology 2014, 50, 210-219. [CrossRef]

247. Banerjee, A.; Khemka, V.K.; Roy, D.; Dhar, A.; Roy, T.K.S.; Biswas, A.; Mukhopadhyay, B.; Chakrabarti, S. Role of pro-inflammatory cytokines and vitamin D in probable Alzheimer's disease with depression. Aging Dis. 2017, 8, 267. [CrossRef]

248. Verma, D.; Wood, J.; Lach, G.; Herzog, H.; Sperk, G.; Tasan, R. Hunger promotes fear extinction by activation of an amygdala microcircuit. Neuropsychopharmacology 2016, 41, 431-439. [CrossRef] [PubMed]

249. Ghosal, S.; Myers, B.; Herman, J.P. Role of central glucagon-like peptide-1 in stress regulation. Physiol. Behav. 2013, 122, 201-207. [CrossRef] [PubMed] 
250. Meyer, R.M.; Burgos-Robles, A.; Liu, E.; Correia, S.S.; Goosens, K.A. A ghrelin-growth hormone axis drives stress-induced vulnerability to enhanced fear. Mol. Psychiatry 2014, 19, 1284-1294. [CrossRef] [PubMed]

251. Lam, V.; Su, J.; Koprowski, S.; Hsu, A.; Tweddell, J.S.; Rafiee, P.; Gross, G.J.; Salzman, N.H.; Baker, J.E. Intestinal microbiota determine severity of myocardial infarction in rats. FASEB J. 2012, 26, 1727-1735. [CrossRef]

252. Iyer, L.M.; Aravind, L.; Coon, S.L.; Klein, D.C.; Koonin, E.V. Evolution of cell-cell signaling in animals: Did late horizontal gene transfer from bacteria have a role? Trends Genet. 2004, 20, 292-299. [CrossRef]

253. Nicolucci, A.C.; Hume, M.P.; Martínez, I.; Mayengbam, S.; Walter, J.; Reimer, R.A. Prebiotics reduce body fat and alter intestinal microbiota in children who are overweight or with obesity. Gastroenterology 2017, 153, 711-722. [CrossRef]

254. Hume, M.P.; Nicolucci, A.C.; Reimer, R.A. Prebiotic supplementation improves appetite control in children with overweight and obesity: A randomized controlled trial. Am. J. Clin. Nutr. 2017, 105, 790-799. [CrossRef]

255. Black, C.N.; Bot, M.; Scheffer, P.G.; Cuijpers, P.; Penninx, B.W. Is depression associated with increased oxidative stress? A systematic review and meta-analysis. Psychoneuroendocrinology 2015, 51, 164-175. [CrossRef]

256. Zheng, P.; Wang, Y.; Chen, L.; Yang, D.; Meng, H.; Zhou, D.; Zhong, J.; Lei, Y.; Melgiri, N.; Xie, P. Identification and validation of urinary metabolite biomarkers for major depressive disorder. Mol. Cell. Proteom. 2013, 12, 207-214. [CrossRef]

257. Zheng, P.; Zeng, B.; Zhou, C.; Liu, M.; Fang, Z.; Xu, X.; Zeng, L.; Chen, J.; Fan, S.; Du, X. Gut microbiome remodeling induces depressive-like behaviors through a pathway mediated by the host's metabolism. Mol. Psychiatry 2016, 21, 786-796. [CrossRef]

258. Eren, I.; Nazıroğlu, M.; Demirdaş, A.; Çelik, Ö.; Uğuz, A.C.; Altunbaşak, A.; Özmen, İ.; Uz, E. Venlafaxine modulates depression-induced oxidative stress in brain and medulla of rat. Neurochem. Res. 2007, 32, 497-505. [CrossRef] [PubMed]

259. Kodydková, J.; Vávrová, L.; Zeman, M.; Jirák, R.; Macášek, J.; Staňková, B.; Tvrzická, E.; Žák, A. Antioxidative enzymes and increased oxidative stress in depressive women. Clin. Biochem. 2009, 42, 1368-1374. [CrossRef] [PubMed]

260. Rybka, J.; Kędziora-Kornatowska, K.; Banaś-Leżańska, P.; Majsterek, I.; Carvalho, L.A.; Cattaneo, A.; Anacker, C.; Kędziora, J. Interplay between the pro-oxidant and antioxidant systems and proinflammatory cytokine levels, in relation to iron metabolism and the erythron in depression. Free Radic. Biol. Med. 2013, 63, 187-194. [CrossRef] [PubMed]

261. Bilici, M.; Efe, H.; Köroğlu, M.A.; Uydu, H.A.; Bekaroğlu, M.; Değer, O. Antioxidative enzyme activities and lipid peroxidation in major depression: Alterations by antidepressant treatments. J. Affect. Disord. 2001, 64, 43-51. [CrossRef]

262. Gałecki, P.; Szemraj, J.; Bieńkiewicz, M.; Florkowski, A.; Gałecka, E. Lipid peroxidation and antioxidant protection in patients during acute depressive episodes and in remission after fluoxetine treatment. Pharmacol. Rep. 2009, 61, 436-447. [CrossRef]

263. Brites, D.; Fernandes, A. Neuroinflammation and depression: Microglia activation, extracellular microvesicles and microRNA dysregulation. Front. Cell. Neurosci. 2015, 9, 476. [CrossRef]

264. Rudzki, L.; Maes, M. The microbiota-gut-immune-glia (MGIG) axis in major depression. Mol. Neurobiol. 2020, 57, 4269-4295. [CrossRef]

265. Delgado, S.; Sánchez, B.; Margolles, A.; Ruas-Madiedo, P.; Ruiz, L. Molecules produced by probiotics and intestinal microorganisms with immunomodulatory activity. Nutrients 2020, 12, 391. [CrossRef]

266. Van Eeden, W.A.; van Hemert, A.M.; Carlier, I.V.; Penninx, B.W.; Lamers, F.; Fried, E.I.; Schoevers, R.; Giltay, E.J. Basal and LPS-stimulated inflammatory markers and the course of individual symptoms of depression. Transl. Psychiatry 2020, 10, 1-12. [CrossRef]

267. Parker, A.; Fonseca, S.; Carding, S.R. Gut microbes and metabolites as modulators of blood-brain barrier integrity and brain health. Gut Microbes 2020, 11, 135-157. [CrossRef]

268. Sandhu, K.V.; Sherwin, E.; Schellekens, H.; Stanton, C.; Dinan, T.G.; Cryan, J.F. Feeding the microbiota-gut-brain axis: Diet, microbiome, and neuropsychiatry. Transl. Res. 2017, 179, $223-244$. [CrossRef] [PubMed] 
269. Magnusson, K.; Hauck, L.; Jeffrey, B.; Elias, V.; Humphrey, A.; Nath, R.; Perrone, A.; Bermudez, L. Relationships between diet-related changes in the gut microbiome and cognitive flexibility. Neuroscience 2015, 300, 128-140. [CrossRef] [PubMed]

270. Wu, G.D.; Chen, J.; Hoffmann, C.; Bittinger, K.; Chen, Y.-Y.; Keilbaugh, S.A.; Bewtra, M.; Knights, D.; Walters, W.A.; Knight, R. Linking long-term dietary patterns with gut microbial enterotypes. Science 2011, 334, 105-108. [CrossRef] [PubMed]

271. Duncan, S.H.; Belenguer, A.; Holtrop, G.; Johnstone, A.M.; Flint, H.J.; Lobley, G.E. Reduced dietary intake of carbohydrates by obese subjects results in decreased concentrations of butyrate and butyrate-producing bacteria in feces. Appl. Environ. Microbiol. 2007, 73, 1073-1078. [CrossRef]

272. Li, J.-M.; Yu, R.; Zhang, L.-P.; Wen, S.-Y.; Wang, S.-J.; Zhang, X.-Y.; Xu, Q.; Kong, L.-D. Dietary fructose-induced gut dysbiosis promotes mouse hippocampal neuroinflammation: A benefit of short-chain fatty acids. Microbiome 2019, 7, 98. [CrossRef]

273. De Filippis, F.; Pellegrini, N.; Vannini, L.; Jeffery, I.B.; La Storia, A.; Laghi, L.; Serrazanetti, D.I.; Di Cagno, R.; Ferrocino, I.; Lazzi, C. High-level adherence to a Mediterranean diet beneficially impacts the gut microbiota and associated metabolome. Gut 2016, 65, 1812-1821. [CrossRef]

274. Fava, F.; Gitau, R.; Griffin, B.; Gibson, G.; Tuohy, K.; Lovegrove, J. The type and quantity of dietary fat and carbohydrate alter faecal microbiome and short-chain fatty acid excretion in a metabolic syndrome 'at-risk'population. Int. J. Obes. 2013, 37, 216-223. [CrossRef]

275. Rienks, J.; Dobson, A.; Mishra, G. Mediterranean dietary pattern and prevalence and incidence of depressive symptoms in mid-aged women: Results from a large community-based prospective study. Eur. J. Clin. Nutr. 2013, 67, 75-82. [CrossRef]

276. Lai, J.S.; Hiles, S.; Bisquera, A.; Hure, A.J.; McEvoy, M.; Attia, J. A systematic review and meta-analysis of dietary patterns and depression in community-dwelling adults. Am. J. Clin. Nutr. 2014, 99, 181-197. [CrossRef]

277. Molendijk, M.; Molero, P.; Sánchez-Pedreño, F.O.; Van der Does, W.; Martínez-González, M.A. Diet quality and depression risk: A systematic review and dose-response meta-analysis of prospective studies. J. Affect. Disord. 2018, 226, 346-354. [CrossRef]

278. Le Port, A.; Gueguen, A.; Kesse-Guyot, E.; Melchior, M.; Lemogne, C.; Nabi, H.; Goldberg, M.; Zins, M.; Czernichow, S. Association between dietary patterns and depressive symptoms over time: A 10-year follow-up study of the GAZEL cohort. PLoS ONE 2012, 7, e51593. [CrossRef] [PubMed]

279. Larrieu, T.; Layé, S. Food for mood: Relevance of nutritional omega-3 fatty acids for depression and anxiety. Front. Physiol. 2018, 9, 1047. [CrossRef] [PubMed]

280. Al-Farsi, Y.M.; Waly, M.I.; Deth, R.C.; Al-Sharbati, M.M.; Al-Shafaee, M.; Al-Farsi, O.; Al-Khaduri, M.M.; Al-Adawi, S.; Hodgson, N.W.; Gupta, I. Impact of nutrition on serum levels of docosahexaenoic acid among Omani children with autism. Nutrition 2013, 29, 1142-1146. [CrossRef] [PubMed]

281. Kempuraj, D.; Tagen, M.; Iliopoulou, B.; Clemons, A.; Vasiadi, M.; Boucher, W.; House, M.; Wolfberg, A.; Theoharides, T. Luteolin inhibits myelin basic protein-induced human mast cell activation and mast cell-dependent stimulation of Jurkat T cells. Br. J. Pharmacol. 2008, 155, 1076-1084. [CrossRef]

282. Zakharevich, N.V.; Averina, O.V.; Klimina, K.M.; Kudryavtseva, A.V.; Kasianov, A.S.; Makeev, V.J.; Danilenko, V.N. Complete genome sequence of Bifidobacterium longum GT15: Unique genes for Russian strains. Genome Announc. 2014, 2. [CrossRef]

283. Dyakov, I.N.; Mavletova, D.A.; Chernyshova, I.N.; Snegireva, N.A.; Gavrilova, M.V.; Bushkova, K.K.; Dyachkova, M.S.; Alekseeva, M.G.; Danilenko, V.N. FN3 protein fragment containing two type III fibronectin domains from B. longum GT15 binds to human tumor necrosis factor alpha in vitro. Anaerobe 2020, 65, 102247. [CrossRef]

284. Goh, K.K.; Liu, Y.-W.; Kuo, P.-H.; Chung, Y.-C.E.; Lu, M.-L.; Chen, C.-H. Effect of probiotics on depressive symptoms: A meta-analysis of human studies. Psychiatry Res. 2019, 282, 112568. [CrossRef]

285. Yong, S.J.; Tong, T.; Chew, J.; Lim, W.L. Antidepressive Mechanisms of Probiotics and Their Therapeutic Potential. Front. Neurosci. 2020, 13, 1361. [CrossRef]

286. Tian, P.; O’Riordan, K.J.; Lee, Y.-K.; Wang, G.; Zhao, J.; Zhang, H.; Cryan, J.F.; Chen, W. Towards a psychobiotic therapy for depression: Bifidobacterium breve CCFM1025 reverses chronic stress-induced depressive symptoms and gut microbial abnormalities in mice. Neurobiol. Stress 2020, 12, 100216. [CrossRef] 
287. Logan, A.C.; Katzman, M. Major depressive disorder: Probiotics may be an adjuvant therapy. Med. Hypotheses 2005, 64, 533-538. [CrossRef]

288. Yunes, R.; Poluektova, E.; Vasileva, E.; Odorskaya, M.; Marsova, M.; Kovalev, G.; Danilenko, V. A multi-strain potential probiotic formulation of GABA-producing Lactobacillus plantarum 90sk and bifidobacterium adolescentis 150 with antidepressant effects. Probiotics Antimicrob. Proteins 2020, 12, 973-979. [CrossRef] [PubMed]

289. Martin, T.C.; Visconti, A.; Spector, T.D.; Falchi, M. Conducting metagenomic studies in microbiology and clinical research. Appl. Microbiol. Biotechnol. 2018, 102, 8629-8646. [CrossRef] [PubMed]

290. O'Leary, N.A.; Wright, M.W.; Brister, J.R.; Ciufo, S.; Haddad, D.; McVeigh, R.; Rajput, B.; Robbertse, B.; Smith-White, B.; Ako-Adjei, D. Reference sequence (RefSeq) database at NCBI: Current status, taxonomic expansion, and functional annotation. Nucleic Acids Res. 2016, 44, D733-D745. [CrossRef] [PubMed]

291. Rekdal, V.M.; Bess, E.N.; Bisanz, J.E.; Turnbaugh, P.J.; Balskus, E.P. Discovery and inhibition of an interspecies gut bacterial pathway for Levodopa metabolism. Science 2019, 364, eaau6323. [CrossRef]

292. Kanehisa, M.; Sato, Y.; Kawashima, M.; Furumichi, M.; Tanabe, M. KEGG as a reference resource for gene and protein annotation. Nucleic Acids Res. 2016, 44, D457-D462. [CrossRef]

293. Caspi, R.; Billington, R.; Ferrer, L.; Foerster, H.; Fulcher, C.A.; Keseler, I.M.; Kothari, A.; Krummenacker, M.; Latendresse, M.; Mueller, L.A. The MetaCyc database of metabolic pathways and enzymes and the BioCyc collection of pathway/genome databases. Nucleic Acids Res. 2016, 44, D471-D480. [CrossRef]

294. Kovtun, A.; Averina, O.; Zakharevich, N.; Kasianov, A.; Danilenko, V. In silico identification of metagenomic signature describing neurometabolic potential of normal human gut microbiota. Russ. J. Genet. 2018, 54, 1101-1110. [CrossRef]

295. Zhu, F.; Ju, Y.; Wang, W.; Wang, Q.; Guo, R.; Ma, Q.; Sun, Q.; Fan, Y.; Xie, Y.; Yang, Z. Metagenome-wide association of gut microbiome features for schizophrenia. Nat. Commun. 2020, 11, 1-10. [CrossRef]

Publisher's Note: MDPI stays neutral with regard to jurisdictional claims in published maps and institutional affiliations.

(C) 2020 by the authors. Licensee MDPI, Basel, Switzerland. This article is an open access article distributed under the terms and conditions of the Creative Commons Attribution (CC BY) license (http://creativecommons.org/licenses/by/4.0/). 